\title{
Study of Ruthenium-Contamination Effect on Oxygen Reduction Activity of Platinum-based PEMFC and DMFC Cathode Catalyst
}

\author{
D. Kaplan ${ }^{a, b,+}$, P. Tereshchuk ${ }^{c, t}$, C. Olewsky ${ }^{a+}$, L. Keinan ${ }^{b}$, O. Ben-Yehuda ${ }^{b}$, M. Shviro ${ }^{d}$, A. Natan ${ }^{c^{*}}$ \\ and E. Peled ${ }^{a^{*}}$ \\ a School of Chemistry, Faculty of Exact Sciences, Tel Aviv University, Tel Aviv, Israel, 69978 \\ ${ }^{b}$ Nuclear Research Center - Negev, Beer-Sheva, Israel, 84190 \\ ' Department of Physical Electronics, Tel Aviv University, Tel Aviv, Israel, 69978 \\ d Institute of Energy and Climate Research, IEK-14, Forschungszentrum Jülich, Jülich, Germany, 52428 \\ Corresponding authors email addresses: peled@tauex.tau.ac.il, amirnatan@post.tau.ac.il \\ ${ }^{+}$These authors had equal contribution
}

\section{$\underline{\text { Abstract }}$}

We outline a systematic experimental and theoretical study on the influence of ruthenium contamination on the oxygen reduction activity (ORR) of a $\mathrm{Pt} / \mathrm{C}$ catalyst at potentials relevant to a polymer electrolyte fuel cell cathode. A commercial $\mathrm{Pt} / \mathrm{C}$ catalyst was contaminated by different amounts of ruthenium, equivalent to $0.15-4$ monolayers. The resulting ruthenium-contaminated $\mathrm{Pt} / \mathrm{C}$ powders were characterized by Energy-Dispersive X-ray Spectroscopy (EDS), X-ray Photoelectron Spectroscopy (XPS) and Scanning Transmission Electron Microscopy (STEM) to verify ruthenium contamination. A rotating disk electrode (RDE) technique was used to study the influence of ruthenium on oxygen reduction kinetics. Density functional theory (DFT) calculations were performed to estimate the oxygen reduction activity of the platinum surface with increasing ruthenium coverage, simulating ruthenium-contaminated $\mathrm{Pt} / \mathrm{C}$. The binding energies of $\mathrm{O}$ and $\mathrm{OH}$ on the surfaces were used for activity estimations. It was found that the specific activity of the ORR at $0.85 \mathrm{~V}$ vs RHE exhibited a pseudoexponential decay with increased ruthenium contamination, decreasing by $\sim 45 \%$ already at 0.15 monolayer-equivalent contamination. The results of the DFT calculations were qualitatively in line with experimental findings, verifying the effect of $\mathrm{O}$ and $\mathrm{OH}$ binding energies and the oxophilic nature of ruthenium on $\mathrm{ORR}$ and the 
ability of the chosen approach to predict the effect of ruthenium contamination on ORR on platinum.

Keywords: ruthenium, oxygen reduction reaction, platinum, binding energies, ORR activity, DFT.

\section{Introduction}

Hydrogen-fed Polymer Electrolyte Membrane Fuel Cells (PEMFCs) and their closely related Direct Methanol Fuel Cells (DMFCs) are considered to be promising energy generators for electric vehicles (EVs), backup or off-grid power and mobile electronic devices $[1,2]$. Despite intensive research over the last three decades, performance, durability and cost issues are still major obstacles to successful widespread commercialization of PEM-type FCs.

One of the reasons for cost challenges of PEMFCs and DMFCs is the fact that carbonsupported nano-size platinum $(\mathrm{Pt} / \mathrm{C})$ is used as the catalyst on the anode and cathode. In reformate-based PEMFCs, the hydrogen stream to the anode contains $\mathrm{CO}$ produced by reforming or partial oxidation of hydrocarbons or alcohols and by a reverse-shift reaction of $\mathrm{CO}_{2}[3,4]$. In DMFCs, direct oxidation of methanol on the anode to $\mathrm{CO}_{2}$ progresses with production of mainly $\mathrm{CO}$ as an intermediate. Even very low concentrations of $\mathrm{CO}(10 \mathrm{ppm})$ in a reformate-based $\mathrm{H}_{2}$ poison $\mathrm{Pt} / \mathrm{C}$ catalysts [5] by strongly adsorbing on the platinum surface, hence reducing the available electrochemically active surface area and seriously inhibiting catalysis of $\mathrm{H}_{2}$ oxidation. Likewise, in DMFCs, CO (an intermediate of methanol oxidation) is adsorbed on platinum, preventing catalysis of methanol oxidation. To solve this CO-poisoning 
problem, platinum-ruthenium (PtRu) alloys are used as anode catalysts. The ruthenium component provides the oxygen-containing species needed to oxidize $\mathrm{CO}$ to $\mathrm{CO}_{2}$ and release the platinum surface for further fuel oxidation $[6,7]$.

However, PtRu catalysts were found to be prone to preferential dissolution of ruthenium [8], especially in the presence of methanol [9]. Ruthenium dissolution from the anode catalyst results in a loss of ruthenium and changes to its $\mathrm{Pt}$ :Ru ratio. This change leads to reduced CO tolerance and methanol oxidation activity [10] of the catalyst (for reformate-based PEMFCs and DMFCs, respectively) that will translate to higher overpotentials of the anode [11].

Ruthenium ions leaving the anode enter the Nafion membrane and cross it to deposit on the platinum cathode catalyst. Ruthenium crossover and its deposition on the cathode in DMFCs were first reported by Piela et al. of the Los Alamos Group [12]. Their pioneering work showed, with the use of XRF and CO-stripping, the presence of ruthenium in the membrane and the cathode already after MEA humidification (the socalled current-less contamination) and after operating a DMFC under various operating conditions (the so-called current-assisted contamination). Cathode contamination resulted in a voltage drop of $25 \mathrm{mV}$ in an $\mathrm{H}_{2}$ /air-operated fuel cell across the entire current density range. This voltage drop was ascribed to lowered catalytic activity of oxygen reduction on the Ru-contaminated cathode. Schoekel et al. reported ruthenium dissolution and deposition on the cathode already during fabrication of the MEA by decal transfer process [13]. Rapid ruthenium contamination of the cathode was recorded during early operation time (two hours) of a DMFC, and was attributed to dissolution of highly soluble ruthenium species in the anode catalyst (Johnson Matthey HiSPEC 12100). Following that, a slower contamination process was recorded, attributed to 
dissolution of less soluble ruthenium oxides or ruthenium from the platinum-ruthenium alloy phase.

The negative effect of ruthenium contamination on the catalytic activity of the ORR demonstrated by Piela et al. [12], is consistent with studies of ORR kinetics on ruthenium and PtRu surfaces. Anastasijević et al. [14] studied the ORR mechanism and kinetics on a ruthenium rod. Their results clearly showed that ruthenium has poor ORR activity at potentials relevant to the PEMFC cathode. A similar conclusion can be drawn from the studies of ORR on electrodeposited ruthenium on a gold disk by MetikošHuković et al. [15] and ruthenium nanoparticles by Cao et al. [16]. Stamenkovic et al. [17] demonstrated the poor ORR activity of the polycrystalline PtRu (1:1) alloy electrode in comparison to the polycrystalline platinum electrode. The negative impact of ruthenium presence on ORR catalytic activity can also be seen in the case of $\mathrm{Pt} / \mathrm{Ru}$ nanoparticles with exposed ruthenium on the surface $[18,19]$.

Gancs et al. have studied the effect of platinum contamination by ruthenium on ORR catalysis [20]. In their study, different concentrations of ruthenium ions were used to contaminate commercial Pt/C by spontaneous deposition of ruthenium. With the use of different concentrations of ruthenium ions, several degrees of Ru-contamination were produced, thus enabling the study of the effect of contamination degree on $\mathrm{CV}$ polarization curves and ORR kinetics. Continuous suppression of $\mathrm{H}_{\text {upd }}$ stripping peaks with increased Ru-contamination was recorded, as well as severe decrease in ORR kinetics as evidenced by RDE polarization curves and Tafel plots. Quite close Tafel slopes were recorded for clean and Ru-contaminated Pt/C (-122 mV/dec vs $113 \mathrm{mV} / \mathrm{dec}$ respectively), indicating an identical ORR mechanism (at least at low overpotentials) for which ruthenium contamination is not a factor. Interestingly, at ruthenium coverage 
of 0.18 monolayer (ML), Ru ORR kinetics reached a minimum value and a maximum overpotential of $\sim 160 \mathrm{mV}$ was recorded.

In this work we studied the influence of ruthenium contamination on ORR kinetics with the use of a commercial Pt/C catalyst (Johnson Matthey HiSPEC8000) that was Rucontaminated. Various and precisely known amounts of ruthenium were deposited on platinum by electroless deposition at $90^{\circ} \mathrm{C}$ with methanol as the reducing agent. This resulted in $\mathrm{Pt} / \mathrm{C}$ catalysts contaminated with different coverage levels of ruthenium. This deposition method was chosen to mimic the existing conditions in a DMFC cathode (approximated working temperature and presence of methanol which had crossed from the anode). The effect of ruthenium on ORR performance was measured by cyclic voltammetry with an RDE. We believe that this simple approach has allowed us to correlate between precisely known ruthenium contamination of $\mathrm{Pt} / \mathrm{C}$ and its ORR kinetics behavior. To explain the effect of Ru contamination on the ORR activity, DFT simulations were performed for the adsorption of $\mathrm{Ru}$ atoms on the $\operatorname{Pt}(111)$ surface and their effect on the $\mathrm{O}$ and $\mathrm{OH}$ binding energies. We then followed the analysis performed by Nørksov et al. [21] to correlate the calculated binding energies with a model estimate for the ORR activity. We showed that the theoretically obtained ORR activity trends have good qualitative agreement with the experimental trend. The combined experimental and theoretical work leads to a deeper understanding of the effect of platinum contamination by a sub-monolayer to a few monolayers of ruthenium on ORR kinetics and potential losses in PEMFCs and DMFCs. 


\section{Experimental and Theoretical Methods}

\section{Catalyst synthesis}

The Ru-contaminated catalysts were prepared by electroless deposition of ruthenium on commercial 50\% Pt/C (HiSPEC8000, Johnson Matthey) with methanol as the reducing agent. For each catalyst, the total amount of deposited ruthenium was equivalent to $0.15-4(0.15,0.22,0.6,1,2,4)$ monolayers of ruthenium. The calculation of the required amount of ruthenium for each catalyst was made on the basis of the atomic radius of ruthenium and an approximation of spherical platinum nanoparticles with a surface area of $60 \mathrm{~m}^{2} \mathrm{~g}_{\mathrm{Pt}}^{-1}$ (manufacturer's data). The catalysts were named according to the amount of deposited ruthenium: $0.15 \mathrm{ML} \mathrm{Ru} / \mathrm{Pt}, 0.22 \mathrm{ML} \mathrm{Ru} / \mathrm{Pt}, 0.6 \mathrm{ML}$ $\mathrm{Ru} / \mathrm{Pt}, 1 \mathrm{ML} \mathrm{Ru} / \mathrm{Pt}, 2 \mathrm{ML} \mathrm{Ru} / \mathrm{Pt}, 4 \mathrm{ML} \mathrm{Ru} / \mathrm{Pt}$.

For the synthesis, $0.2 \mathrm{~g}$ of HiSPEC 8000 was dispersed by vigorous magnetic stirring in an aqueous solution of $1 \mathrm{M}$ methanol at room temperature. The suspension was heated to $\sim 90{ }^{\circ} \mathrm{C}$ while being refluxed. A desired amount of $\mathrm{RuCl}_{3} \cdot 3 \mathrm{H}_{2} \mathrm{O}$ was dissolved in 10 $\mathrm{mL}$ of $0.4 \mathrm{M} \mathrm{HCl}$ solution and added to the suspension at a rate of $1 \mathrm{~mL}$ every 15 minutes while the suspension temperature was maintained at $\sim 90{ }^{\circ} \mathrm{C}$. On completing the addition of ruthenium solution, the mixture was refluxed for an additional 30 minutes and then cooled to room temperature. The catalytic powder was recovered by centrifugation, washed with DI water until no chloride ions could be detected and dried.

\section{Electrochemical characterization}

All electrochemical experiments were performed at a controlled temperature $\left(25 \pm 1{ }^{\circ} \mathrm{C}\right)$ with the use of a custom-made three-compartment glass cell with an $\mathrm{Ag} / \mathrm{AgCl} / 3 \mathrm{M} \mathrm{KCl}$ reference electrode in a Luggin-capillary compartment and a platinum wire as a counter 
electrode. A $0.5 \mathrm{M} \mathrm{H}_{2} \mathrm{SO}_{4}$ solution was used as the electrolyte. All potentials are reported on the reversible-hydrogen-electrode (RHE) scale.

Measurements of the electrochemically active surface area (ECSA) of $\mathrm{Ru} / \mathrm{Pt} / \mathrm{C}$ were carried out by the $\mathrm{Cu}_{\text {upd }}$ stripping method [22], described in detail in our previous publication [23]. The working electrode was a $1 \mathrm{~cm} \times 5 \mathrm{~cm}$ glassy-carbon rectangle. The catalytic ink consisted of $10 \mathrm{mg}$ of catalyst powder, $5 \%(\mathrm{w} / \mathrm{w})$ Nafion solution, $7.5 \mathrm{~mL}$ DI $\mathrm{H}_{2} \mathrm{O}, 2.5 \mathrm{~mL}$ EtOH and $\mathrm{XC} 72$ that was added to obtain a concentration of 0.2-0.3 $\%(\mathrm{w} / \mathrm{w})$ solids in the ink. This concentration range of solids allowed obtaining a stable ink. The Nafion volume was adjusted to be $\sim 30 \%(\mathrm{v} / \mathrm{v})$ of the solids in the inks. The ink was dispersed for 60 minutes in an ultrasonic ice-water bath, with additional fiveminute dispersion by pulse sonication (also in an ice-water bath) with the use of a horn sonicator (Heilscher UP200st). Immediately after sonication, $10 \mu \mathrm{L}$ of the catalytic ink was applied to the lower part of the working electrode.

Nitrogen (99.999\% purity) was bubbled through a $0.5 \mathrm{M} \mathrm{H}_{2} \mathrm{SO}_{4}$ solution for 30 minutes before electrochemical experiments and then passed over the solution during the entire procedure. Prior to ECSA measurements, the working electrodes were conditioned in order to clean their surface. A common conditioning procedure of $\mathrm{Pt}$ and $\mathrm{Pt} / \mathrm{C}$ catalysts consists of repetitive cycling in deaerated electrolyte over a potential range of 0-1.2/1.4 volts until a stable voltammogram is obtained [24]. Cycling of $\mathrm{Ru} / \mathrm{Pt} / \mathrm{C}$ catalysts above $750 \mathrm{mV}$ might lead to substantial ruthenium dissolution that would result in unintended surface modification of these catalysts $[9,25]$. Hence, to reduce the possibility of ruthenium dissolution, the conditioning procedure of $\mathrm{Ru} / \mathrm{Pt} / \mathrm{C}$ catalysts was limited to 0-750 $\mathrm{mV}$ potential range [26].

For ORR measurements, a 5mm-diameter glassy-carbon RDE (Pine Instruments, USA) with $A_{\text {geo }}=0.196 \mathrm{~cm}^{2}$ was used. The RDE was polished to a mirror finish with a 
$0.05 \mu \mathrm{m} \mathrm{Al}{ }_{2} \mathrm{O}_{3}$ particle suspension on a moistened polishing Micro-Cloth (both from Buehler). The electrode was mounted on an interchangeable RDE holder connected to an electrode rotator (MSRX electrode rotator, Pine Instruments, USA).

The catalytic ink for ORR measurements consisted of catalyst powder, XC72 powder, $5 \%$ (w/w) Nafion solution, DI $\mathrm{H}_{2} \mathrm{O}$ and IPA. The Nafion volume was adjusted to 30 $\%(\mathrm{v} / \mathrm{v})$ of the solids in the inks. A catalytic loading of $\sim 20 \mu \mathrm{g}_{\mathrm{PGM}} \mathrm{cm}_{\mathrm{geo}}{ }^{-2}$ on the RDE was used and the weight of catalyst powder, DI $\mathrm{H}_{2} \mathrm{O}$ and IPA volumes ( 30 \%(v/v) IPA [27]) were adjusted accordingly. As in the case of ECSA measurements, addition of XC72 to obtain a concentration of $0.2-0.3 \%(\mathrm{w} / \mathrm{w})$ solids in the ink enabled the preparation of a stable ink and also a uniform catalyst coating on the RDE. The ink was ultrasonically dispersed by the same procedure as the ink used for ECSA measurements, afterwards $10 \mu \mathrm{L}$ of the ink was applied on the RDE.

Several studies have shown that a uniform catalytic film has a beneficial effect on the currents obtained during RDE ORR polarization [28,29]. We have examined different drying procedures of the ink droplet in order to obtain the most uniform film. In our laboratory environment a stationary drying procedure at room temperature with IPA environment consistently produced the most uniform catalytic films. Subsequently, this drying method was used during this research.

Nitrogen (99.999\% purity) was bubbled through a $0.5 \mathrm{M} \mathrm{H}_{2} \mathrm{SO}_{4}$ solution for 30 minutes before electrochemical experiments and then passed over the solution during conditioning and background measurement. iR drop between the working and reference electrodes was measured and consistently found to be $\sim 4 \Omega$. Working electrodes with $\mathrm{Ru} / \mathrm{Pt} / \mathrm{C}$ were conditioned as mentioned above. Working electrodes with $\mathrm{Pt} / \mathrm{C}$ were conditioned by cycling over a potential range of 0-1.2 V. For background measurements, the working electrodes were cycled for five cycles over 0-1V (for 
$\mathrm{Ru} / \mathrm{Pt} / \mathrm{C}$ ) or $0.025-1.2 \mathrm{~V}$ potential range (for $\mathrm{Pt} / \mathrm{C}$ ) at $20 \mathrm{mV} \mathrm{s}^{-1}$. Background measurements were also used to measure ECSA of Pt/C by the $\mathrm{H}_{\text {upd }}$ stripping method [30].

Before ORR measurements, the $\mathrm{O}_{2}(99.999 \%$ purity) was bubbled through the electrolyte for 30 minutes and then passed over the electrolyte during ORR polarization. The RDE potential was cycled between 1 and $0 \mathrm{~V}$ at $20 \mathrm{mV} \mathrm{s}^{-1}$ while the RDE was rotated at $2500 \mathrm{rpm}$ in the $\mathrm{O}_{2}$-saturated electrolyte. The current at $0.85 \mathrm{~V}$ during anodic sweep polarization, after mass transport, background and iR corrections, was taken as a measure of the ORR activity, $j_{k}^{0.85 V}[31]$.

\section{Physicochemical characterization}

Detailed procedures of EDS and XPS measurements were described previously [32,33]. The measurements were made at ten (EDS) and four (XPS) points, respectively, in each sample of homemade catalysts and the results showed no significant inhomogeneity. The reported results are an average of the measurements.

Transmission Electron Microscope (TEM) imaging was performed with an FEI F20 Philips-Tecnai STEM operated at $200 \mathrm{kV}$. Samples were prepared by manually pressing the grid (200-mesh grid, EMS) against the sample powder. TEM images were used to construct particle-size distributions of the catalysts by measuring diameters of at least 80 individual particles with ImageJ software [34].

Elemental mapping was performed with the use of an FEI Titan 80-200 STEM equipped with a Cs-probe corrector (CEOS GmbH). "Z-contrast" conditions were achieved with the use of a probe semiangle of $25 \mathrm{mrad}$ and an inner collection angle of the detector of 68 mrad. During STEM-EDS elemental mapping, HAADF detector and Pt L and Ru L 
peaks were used. Samples were prepared by placing a drop of diluted sample on a 400mesh carbon-coated copper grid.

\section{Theoretical methods and computational details}

Our total energy calculations were carried out with the use of DFT simulations within the Perdew-Burke-Ernzerhof generalized gradient approximation (PBE-GGA) as exchange-correlation energy functional, and the all-electron projected augmented wave (PAW) $[35,36]$ method as implemented in the Vienna Ab initio Simulation Package (VASP) code [37,38]. For the calculations, a plane wave cut-off energy of $500 \mathrm{eV}$ and k-point grids of $10 \times 10 \times 10$ and $6 \times 6 \times 1$ for the bulk and slab surface cells, respectively, were used. Geometric relaxation was considered to be complete once the atomic forces on each atom were smaller than $0.02 \mathrm{eV} \AA^{-1}$, and a total energy convergence of $10^{-6} \mathrm{eV}$ for the structural energy minimization was achieved.

For the bulk fcc Pt, the calculated equilibrium lattice constant is $3.968 \AA$, which is consistent with theoretical findings from the Aflow database [39] and other theoretical $[40,41]$ and experimental $[42,43]$ results. The calculated bulk Ru hcp parameters were $\mathrm{a}=2.721 \AA$ and $\mathrm{c}=4.293 \AA$, also in agreement with the theoretical $[38,44]$ and experimental [45] results.

\section{Modelling of Ru on Pt(111)}

The adsorption of Ru atoms was modelled with different coverage levels (of 0.11, 0.22, 0.44, 1ML, which correspond to 1, 2, 4 and 9 atoms in the surface unit cell) on $\operatorname{Pt}(111)$ applying the repeated slab geometry model with a $3 \times 3$ surface unit cell and five layers in the slab separated by a vacuum region of about $25 \AA$.

A single Ru ad-atom was placed at the hollow and bridge sites over $\operatorname{Pt}(111)$ surface as they are considered to be the most favorable positions. Then, the adsorption of 
additional Ru atoms, such as 2, 4 and $9 \mathrm{Ru}$ atoms, was modelled on the $\mathrm{Pt}(111)$ surface. In order to take into account all possible $\mathrm{Ru}$ geometries, as a starting point for geometrical relaxation, the $\mathrm{Ru}$ atoms were placed as planar and three-dimensional clusters (that is, pyramid-like configurations for $\mathrm{Ru}_{4}$ and $\mathrm{Ru} \mathrm{u}_{9}$ ) and separately diffused atoms over the $\operatorname{Pt}(111)$ surface. Then, geometrical optimization of the initial structures was performed, allowing all atoms to move but freezing the two bottom atomic $\mathrm{Pt}$ layers. Finally, the lowest energy structures were selected according to the total energies of the optimized structures.

\section{Modelling of $\mathrm{O}$ and $\mathrm{OH}$ on $\operatorname{Ru}_{n} \operatorname{Pt}(111)$}

The initial structures for $m \mathrm{O}\left(m=1,2,3\right.$, and 4) atoms on the $\mathrm{Ru}_{n} / \mathrm{Pt}(111)$ surfaces were built on the following basis: $\mathrm{O}$ atoms were placed at hollow, bridge and top sites over $\mathrm{Ru}$ and $\mathrm{Pt}$ atoms. Then the systems were allowed to relax, again freezing the two bottommost Pt layers. The initial structures for $m \mathrm{OH}(m=1,2,3$, and 4) species on the $\mathrm{Ru}_{n} / \operatorname{Pt}(111)$ surfaces were constructed on the basis of the optimized $m \mathrm{O} / \mathrm{Ru}_{n} / \operatorname{Pt}(111)$ structures.

\section{Binding energies, reaction energies and activity}

The following steps were applied for the calculations. First, the binding energies $\left(\mathrm{E}_{b}\right)$ for $\mathrm{O}$ atoms on $\mathrm{Ru}_{n} / \mathrm{Pt}(111)$ surfaces were calculated as $\mathrm{E}_{b}=\left(E\left(\mathrm{mO} / \mathrm{Ru}_{\mathrm{n}} \mathrm{Pt}(111)\right)\right.$ $\left.E\left(\operatorname{Ru}_{\mathrm{n}} \mathrm{Pt}(111)\right)-\mathrm{m} E(\mathrm{O})\right) / m$, where the first, second and third terms are the total energies of the $m \mathrm{O} / \mathrm{Ru}_{n} / \mathrm{Pt}(111), \mathrm{Ru}_{n} / \mathrm{Pt}(111)$ and the $\mathrm{O}$ atoms in gas-phase, respectively. $m$ is the number of $\mathrm{O}$ atoms in the system, the same definition for binding energy was applied also to $\mathrm{OH}(\mathrm{OH}$ replacing $\mathrm{O}$ in all equations). For the estimation of ORR activity, we follow the approach by Nørksov et al. [21], for completeness we repeat the main principles of this approach here. The oxygen reduction reaction can be written as: 


$$
\frac{1}{2} \mathrm{O}_{2}+2 \mathrm{H}^{+}+2 e^{-} \rightarrow \mathrm{H}_{2} \mathrm{O}
$$

As described in [21], in the simplest way, it is possible to consider the following processes at the surface:

$$
\begin{aligned}
& \frac{1}{2} \mathrm{O}_{2}+* \rightarrow \mathrm{O}^{*} \\
& \mathrm{O}^{*}+\mathrm{H}^{+}+e^{-} \rightarrow \mathrm{HO}^{*} \\
& \mathrm{HO}^{*}+\mathrm{H}^{+}+e^{-} \rightarrow \mathrm{H}_{2} \mathrm{O}+*
\end{aligned}
$$

Here "*” implies the pure surface, and $\mathrm{O}^{*}$ and $\mathrm{OH}^{*}$ imply the surface with the adsorbed species. Following [21], we analyze the reaction energies for the reactions:

$$
\begin{aligned}
& \mathrm{H}_{2} \mathrm{O}+* \rightarrow \mathrm{O}^{*}+\mathrm{H}_{2} \\
& \mathrm{H}_{2} \mathrm{O}+* \rightarrow \mathrm{HO}^{*}+\frac{1}{2} \mathrm{H}_{2}
\end{aligned}
$$

We assume that the hydrogen evolution reaction:

$$
H^{+}+e^{-} \rightarrow \frac{1}{2} H_{2}
$$

is in equilibrium for a potential $U_{0}=0$ relative to the standard hydrogen electrode. It is hence evident that the free energy change of reaction 6 is the minus of the change in reaction 4, and that the difference of the free energies of reactions 6 and 5 yields the free energy change of reaction 3. The reaction energies $\left(\Delta E_{\mathrm{O}}\right.$ and $\left.\Delta E_{\mathrm{OH}}\right)$ for reactions 5 and 6 for 1 and $4 \mathrm{O}$ and $\mathrm{OH}$ on all the surfaces were computed on the basis of the total energies of the species as:

$$
\begin{aligned}
& \Delta E_{O}=E\left(H_{2}\right)+E\left(O^{*}\right)-E(*)-E\left(H_{2} O\right) \\
& \Delta E_{O H}=\frac{1}{2} E\left(H_{2}\right)+E\left(O H^{*}\right)-E(*)-E\left(H_{2} O\right)
\end{aligned}
$$

In the case of $m$ oxygen atoms (or OH species), we normalized $\Delta E_{O}$ and $\Delta E_{O H}$ by $m$. In order to account for the effect of the surrounding water molecules in the environment, the VASPSol $[46,47]$ solvation model for water was utilized. 
The free energy difference was calculated as $\Delta G=\Delta E_{\mathrm{O}} / \Delta E_{\mathrm{OH}}+\Delta \mathrm{ZPE}-T \Delta S$, where $\Delta E_{\mathrm{O}} / \Delta E_{\mathrm{OH}}$ is the reaction energy, $\Delta \mathrm{ZPE}$ and $\Delta S$ are the changes in zero-point energies and in entropy, due to the reaction, respectively. The second and third terms in the expression are calculated by DFT and were taken by us from [21], where $\triangle \mathrm{ZPE}-T \Delta S$ are $0.35 \mathrm{eV}$ for $\left(\mathrm{OH}^{*}+1 / 2 \mathrm{H}_{2}\right)$ and $0.05 \mathrm{eV}$ for $\left(\mathrm{O}^{*}+\mathrm{H}_{2}\right)$.

For a general potential $U_{0}, \Delta \mathrm{G}_{x}\left(\mathrm{U}_{0}\right)$ can be calculated as

$$
\begin{gathered}
\Delta \mathrm{G}_{0}\left(\mathrm{U}_{0}\right)=\Delta \mathrm{G}_{\mathrm{O}}-2 \mathrm{eU}_{0}, \\
\Delta \mathrm{G}_{1}\left(\mathrm{U}_{0}\right)=\Delta \mathrm{G}_{\mathrm{OH}}-\Delta \mathrm{G}_{\mathrm{O}}+\mathrm{eU}_{0}, \\
\Delta \mathrm{G}_{2}\left(\mathrm{U}_{0}\right)=-\Delta \mathrm{G}_{\mathrm{OH}}+\mathrm{eU}_{0},
\end{gathered}
$$

A potential of $U_{0}=1.23 \mathrm{~V}$ is assumed for the reaction of Eq. 1 to be in equilibrium. From the discussion above it is clear that $\Delta G_{2}$ describes the free-energy change in reaction 4 , and $\Delta G_{1}$ describes the change in reaction 3 , reaction 2 is partially described by $\Delta G_{0}$. In addition, the activation barrier for $\mathrm{O}_{2}$ dissociation at the surface, $\mathrm{E}_{\mathrm{a}}$, was taken according to the universal relation found in $[21,48]$. This relation connects the reaction activation energy and the stability of the reaction intermediates, according to $E_{a}=1.8^{*} \Delta E_{\mathrm{O}}-2.89 \mathrm{eV}$. While this relationship was established for pure surfaces, we have also extended it to our case.

The values of $\Delta G_{0}\left(U_{0}\right), \Delta G_{2}\left(U_{0}\right), \Delta G_{1}\left(U_{0}\right)$, and $E_{a}$ can be used to calculate the different reaction-rate constants according to: $k_{i} \sim k_{0} e^{-\frac{\Delta G_{i}}{K_{B} T}}$. We can assume that the slowest step determines the overall rate of the reaction. Hence, we [21] define the activity, $A$, $[21,49]$ by the logarithm of the rate constants, as

$$
A=-\max \left(\Delta G_{0}\left(\mathrm{U}_{0}\right), \Delta G_{1}\left(\mathrm{U}_{0}\right), \Delta G_{2}\left(\mathrm{U}_{0}\right), E_{a}\right) .
$$

A is proportional to the logarithm of the lowest reaction-rate constant.

\section{$\underline{\text { Results and discussion }}$}

\section{Structure and composition analysis}

Weight and atomic compositions based on SEM-EDS and XPS analyses (before and after sputtering) of Ru-contaminated catalysts are shown in Table I. Both SEM-EDS and XPS show an increasing at $\%$ of ruthenium as its experimentally planned monolayer number increases, from $\mathrm{Ru}_{4} \mathrm{Pt}_{96}$ (SEM-EDS) and $\mathrm{Ru}_{7} \mathrm{Pt}_{93}$ (XPS) for 0.15ML Ru/Pt to 
$\mathrm{Ru}_{56} \mathrm{Pt}_{44}$ (EDS) and $\mathrm{Ru}_{65} \mathrm{Pt}_{35}$ (XPS) for 4ML Ru/Pt. The only exception to this trend being $0.22 \mathrm{ML} \mathrm{Ru} / \mathrm{Pt}$ for which a lower at\% of ruthenium than for $0.15 \mathrm{ML} \mathrm{Ru} / \mathrm{Pt}$ was detected by XPS analysis. We believe this anomaly is related to insufficient sensitivity of XPS at such low at\% of ruthenium in both samples. All catalysts show higher at\% of ruthenium on the surface compared to the situation after five minutes of sputtering (determined by XPS) and in the bulk (determined by SEM-EDS). The combined SEMEDS and XPS results are an indication that ruthenium was deposited on platinum nanoparticles during the synthesis and not as separate nanoparticles.

Representative TEM images and size-distribution histograms (insets) of Rucontaminated catalysts, and HiSPEC8000 are presented in Figures S1(a-i) in Supplementary Material. The average particle sizes of Ru-contaminated catalysts are similar to HiSPEC8000 up to $1 \mathrm{ML} \mathrm{Ru} / \mathrm{Pt}(3.7-3.9 \mathrm{~nm})$ and increasing substantially to 4.5-4.6 for 2ML Ru/Pt and 4ML Ru/Pt (Table I). Several Ru/Pt catalysts show increased particle agglomeration compared to HiSPEC8000. Suspecting that the agglomeration was caused by exposure to hot reflux during the synthesis, a suspension containing HiSPEC8000 and methanol but not ruthenium salt was refluxed for the same time as during ruthenium deposition. Indeed, the resulting powder (named HiSPEC8000_M) shows significant agglomeration in TEM images (Figure S1(i) in Supplementary Material) that also manifests itself in ECSA measurements presented later.

Figures 1(a-f) show representative high-resolution STEM-EDS mappings of different Ru-contaminated single nanoparticles, with platinum colored in red and iridium in green. All examined particles of all Ru-contaminated catalysts show the presence of both ruthenium and platinum. It can be clearly seen that ruthenium was deposited on the surface of platinum nanoparticles without creating separate nanoparticles on the carbon support. In addition, with increasing amounts of added ruthenium, higher 
coverage of ruthenium on platinum nanoparticles can be seen. A combination of SEMEDS, XPS and STEM-EDS mapping measurements shows unambiguously that all Rucontaminated catalysts have an Ru-on-Pt structure.

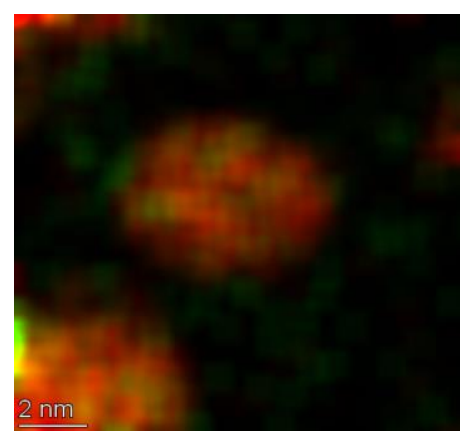

(a) $-0.15 \mathrm{ML} R \mathrm{Ru}$

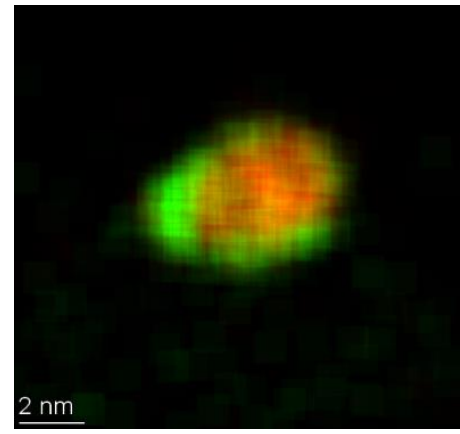

(d) $-1 M L R u$

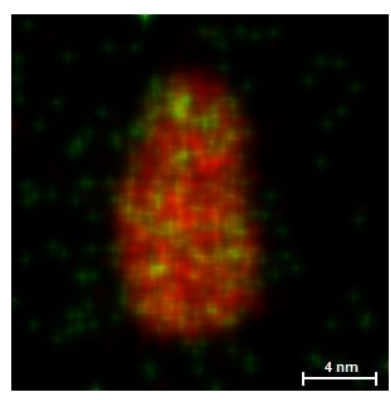

(b) $-0.22 \mathrm{ML} \mathrm{Ru}$

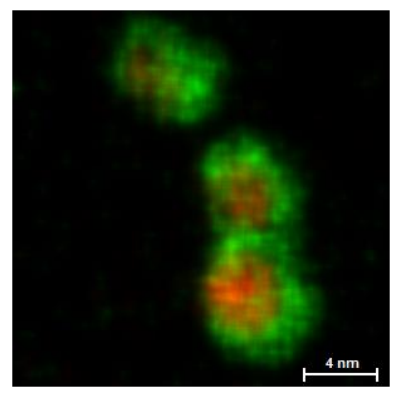

(e) $-2 \mathrm{ML} \mathrm{Ru}$

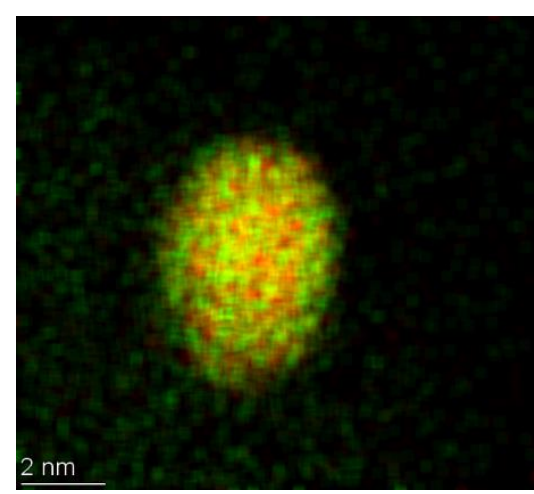

(c) $-0.6 \mathrm{ML} \mathrm{Ru}$

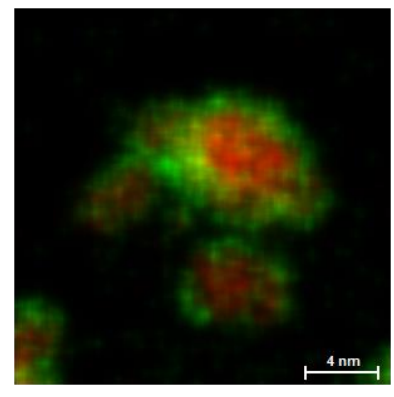

(f) $-4 \mathrm{ML} \mathrm{Ru}$

Figure 1 - HAADF-STEM elemental mapping of Ru-contaminated nanoparticles.

Platinum is marked with red and ruthenium is marked with green. (a) $-0.15 \mathrm{ML}$ $\mathrm{Ru} / \mathrm{Pt}$, (b) - 0.22ML Ru/Pt, (c) - 0.6ML Ru/Pt, (d) - 1ML Ru/Pt, (e) - 2ML Ru/Pt, (f) $-4 \mathrm{ML} \mathrm{Ru} / \mathrm{Pt}$. 


\begin{tabular}{|c|c|c|c|c|c|}
\hline \multicolumn{5}{|c|}{ Table I - Physicochemical characterization results of the examined nanopowders } \\
\hline Nanopowder & $\begin{array}{c}\text { Bulk } \\
\text { wt\% ratio }\end{array}$ & $\begin{array}{c}\text { Bulk at\% } \\
\text { ratio (metals) }\end{array}$ & $\begin{array}{c}\text { Surface at\% } \\
\text { ratio (metals) }\end{array}$ & $\begin{array}{c}\text { Sub-surface* } \\
\text { at\% ratio (metals) }\end{array}$ & $\begin{array}{c}\text { Particle size } \\
\text { [nm] }\end{array}$ \\
\hline HiSPEC8000 & $50 \% \mathrm{Pt} / \mathrm{C}$ & $\mathrm{Pt}_{100}$ & $\mathrm{Pt}_{100}$ & $\mathrm{Pt}_{100}$ & $3.7 \pm 1$ \\
\hline HiSPEC8000_M & $50 \% \mathrm{Pt} / \mathrm{C}$ & $\mathrm{Pt}_{100}$ & $\mathrm{Pt}_{100}$ & $\mathrm{Pt}_{100}$ & $3.9 \pm 1.2$ \\
\hline 0.15ML Ru/Pt/C & $\mathrm{Ru}_{1 \%} / \mathrm{Pt}_{50 \%} / \mathrm{C}$ & $\mathrm{Ru}_{4} / \mathrm{Pt}_{96}$ & $\mathrm{Ru}_{7} / \mathrm{Pt}_{93}$ & $\mathrm{Ru}_{5} / \mathrm{Pt}_{95}$ & $3.8 \pm 1.2$ \\
\hline 0.22ML Ru/Pt/C & $\mathrm{Ru}_{1.5 \%} / \mathrm{Pt}_{48} / \mathrm{C}$ & $\mathrm{Ru}_{6} / \mathrm{Pt}_{94}$ & $\mathrm{Ru}_{5} / \mathrm{Pt}_{95}$ & $\mathrm{Ru}_{3} / \mathrm{Pt}_{97}$ & $3.8 \pm 1.2$ \\
\hline $0.6 \mathrm{ML} \mathrm{Ru} / \mathrm{Pt} / \mathrm{C}$ & $\mathrm{Ru}_{4} / \mathrm{Pt}_{48} / \mathrm{C}$ & $\mathrm{Ru}_{13} / \mathrm{Pt}_{87}$ & $\mathrm{Ru}_{22} / \mathrm{Pt}_{78}$ & $\mathrm{Ru}_{14} / \mathrm{Pt}_{86}$ & $3.7 \pm 0.8$ \\
\hline 1ML Ru/Pt/C & $\mathrm{Ru}_{7} / \mathrm{Pt}_{48} / \mathrm{C}$ & $\mathrm{Ru}_{21} / \mathrm{Pt}_{79}$ & $\mathrm{Ru}_{32} / \mathrm{Pt}_{68}$ & $\mathrm{Ru}_{14} / \mathrm{Pt}_{86}$ & $3.9 \pm 0.8$ \\
\hline 2ML Ru/Pt/C & $\mathrm{Ru}_{17} / \mathrm{Pt}_{47 \%} / \mathrm{C}$ & $\mathrm{Ru}_{36} / \mathrm{Pt}_{64}$ & $\mathrm{Ru}_{50} / \mathrm{Pt}_{50}$ & $\mathrm{Ru}_{41} / \mathrm{Pt}_{59}$ & $4.5 \pm 1$ \\
\hline 4ML Ru/Pt/C & $\mathrm{Ru}_{26 \%} / \mathrm{Pt}_{38 \%} / \mathrm{C}$ & $\mathrm{Ru}_{56} / \mathrm{Pt}_{44}$ & $\mathrm{Ru}_{65} / \mathrm{Pt}_{35}$ & $\mathrm{Ru}_{56} / \mathrm{Pt}_{44}$ & $4.6 \pm 1.1$ \\
\hline
\end{tabular}

*following 5min sputtering time

\section{CV characteristics and ECSA measurement}

Cyclic voltammograms of the catalysts, obtained in deaerated $0.5 \mathrm{M} \mathrm{H}_{2} \mathrm{SO}_{4}$, are presented in Figure 2a (Pt/C only) and Figure 2b (Ru-contaminated Pt/C). Typical platinum-characteristic features $\left(\mathrm{H}_{\mathrm{upd}}\right.$ stripping peaks at roughly $50-350 \mathrm{mV}$ and reduction peak of platinum oxides at roughly $770 \mathrm{mV}$ ) can be seen on the voltammogram of HiSPEC8000. The voltammogram of HiSPEC8000_M shows similar platinum features, however, it is influenced by higher agglomeration of its nanoparticles; all peaks show lower currents compared to untreated HiSPEC8000.

The voltammograms of Ru-contaminated catalysts show a gradual change as the amount of added ruthenium is increased. While $\mathrm{H}_{\text {upd }}$ stripping from the (110) and (100) platinum planes can be clearly seen for $0.15 \mathrm{ML}$, in the cases of $0.22 \mathrm{ML}$ and $0.6 \mathrm{ML}$ $\mathrm{Ru} / \mathrm{Pt}$, the $\mathrm{H}_{\text {upd }}$ stripping from the (100) plane exhibits a shoulder instead of a peak. 

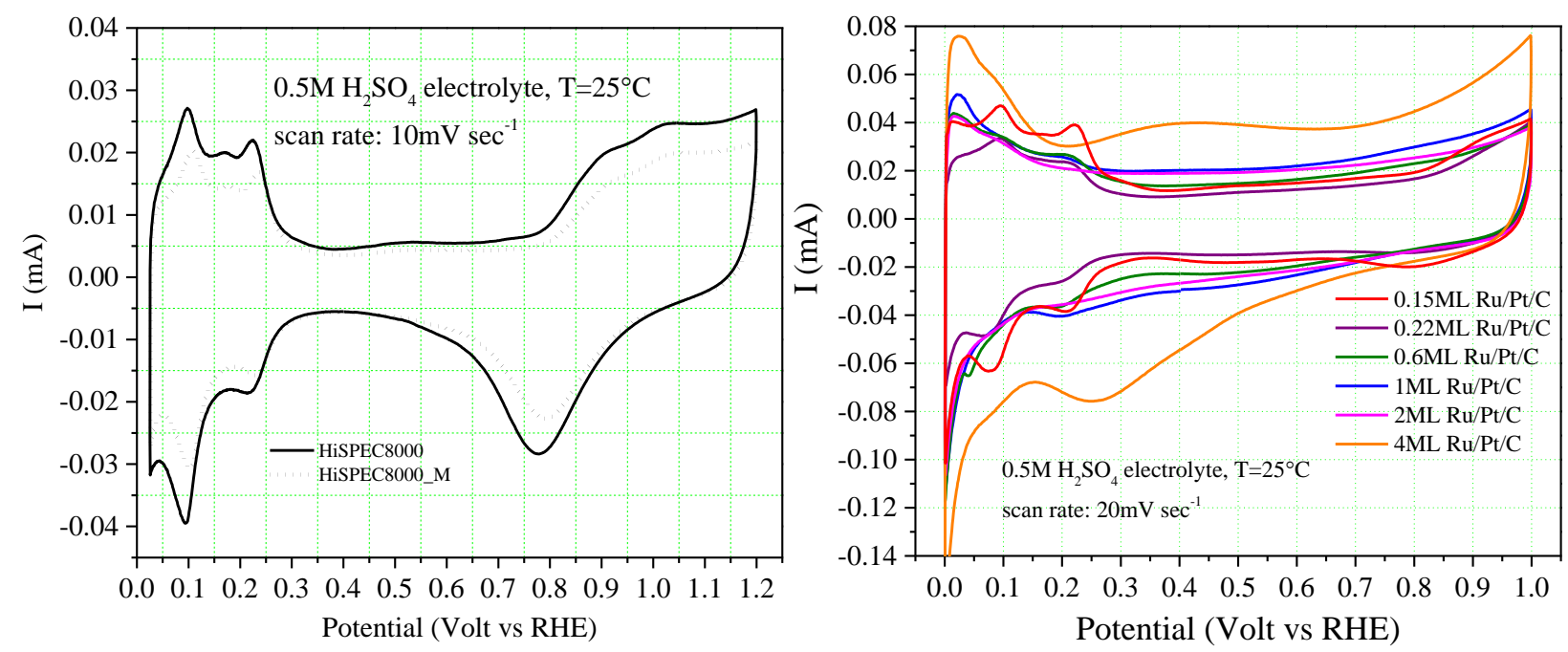

Figure 2 - Polarization voltammograms of the catalysts in deaerated $0.5 \mathrm{M} \mathrm{H}_{2} \mathrm{SO}_{4}$, (a)

HiSPEC8000 and HiSPEC8000_M, (b) Ru-contaminated catalysts.

Only small remnants of platinum-characteristic $\mathrm{H}_{\text {upd }}$ stripping region features can be seen for $1 \mathrm{ML} \mathrm{Ru} / \mathrm{Pt}$ and none can be seen for $2 \mathrm{ML}$ and $4 \mathrm{ML} \mathrm{Ru} / \mathrm{Pt}$, with the latter exhibiting a ruthenium-characteristic region with a large Ru-oxide reduction peak at $\sim 0.25 \mathrm{~V}$ (cathodic scan direction) indicating an Ru-only or highly Ru-enriched surface composition. It is clear that the gradual suppression of the platinum-characteristic $\mathrm{H}_{\text {upd }}$ stripping region is due to the increased ruthenium coverage of platinum. Besides changes in the $\mathrm{H}_{\text {upd }}$ stripping region, the "double layer" region (at roughly $350-750 \mathrm{mV}$ for platinum) exhibits a gradual expansion with increasing ruthenium concentrations. This expansion originates from ruthenium oxidation/reduction [50] and high pseudocapacitance of hydrous ruthenium oxides [51]. The observed changes in the voltammograms are consistent with previously published works $[12,20,50,52]$ that correlated changes in voltammogram features with increased ruthenium content.

The ECSA values obtained are presented in Table II. HiSPEC8000_M shows a decreased ECSA compared to HiSPEC8000 resulting from particle agglomeration mentioned previously. ECSA values of all Ru-contaminated catalysts are lower compared to HiSPEC8000. Generally, ECSA values of nanocatalysts are affected by 
particle size and their agglomeration. It appears that $1 \mathrm{ML} \mathrm{Ru} / \mathrm{Pt}$ had a lower particle agglomeration that led to a higher ECSA value compared to other $\mathrm{Ru} / \mathrm{Pt}$ catalysts with similar particle sizes. On the other hand, 0.6ML Ru/Pt had higher particle agglomeration that led to lower ECSA. ECSA values of $2 \mathrm{ML}$ and $4 \mathrm{ML} \mathrm{Ru} / \mathrm{Pt}$ are on the lower side compared to other Ru/Pt catalysts. This was to be expected in light of the higher amount of ruthenium contamination in these catalysts that led to higher particle sizes.

\section{Experimental study of ORR catalytic activity}

ORR polarization curves of the examined catalysts are shown in Figure 3 and the obtained ORR $j_{k}^{0.85 V}$ values are presented in Table II. Compared to $\mathrm{Pt} / \mathrm{C}$, the polarization curves of $\mathrm{Ru}$-contaminated catalysts show a progressive shift of onset potentials and mixed kinetics/mass-transport regions toward more negative potentials indicating a negative effect of ruthenium contamination on ORR activity at low overpotentials. The overpotential required for reaching a mass-transport-limiting region is also negatively affected: the polarization curves of $1 \mathrm{ML}, 2 \mathrm{ML}$ and $4 \mathrm{ML} \mathrm{Ru} / \mathrm{Pt}$ reach a mass-transport-limiting region at substantially higher overpotentials compared to less contaminated catalysts. The appearance of a mass-transport-limiting region for $4 \mathrm{ML}$ $\mathrm{Ru} / \mathrm{Pt}$, despite its surface being composed of ruthenium, can be attributed to the ability of ruthenium to catalytically facilitate ORR at sufficiently high overpotentials $[14,16]$.

Both $\mathrm{Pt} / \mathrm{C}$ catalysts exhibit similar values of specific activity $\left(j_{k}^{0.85 V}\right)$ of $\sim 2.6 \mathrm{~A} \mathrm{~m}^{-2} \mathrm{Pt}$, eliminating any possible effect of exposure to hot reflux during the synthesis and subsequent agglomeration on ORR specific activity during this research. Specific activity values of Ru-contaminated catalysts decrease with increasing amounts of ruthenium contamination. Even the smallest Ru-contamination $(0.15 \mathrm{ML} \mathrm{Ru})$ leads to 
massive inhibition of ORR at this potential. The largest contamination (2ML Ru and 4ML Ru) leads to practically no ORR activity, which makes both $2 \mathrm{ML}$ and 4ML Ru/Pt completely irrelevant as ORR catalysts for DMFCs and PEMFCs, given their cathode operating potentials.

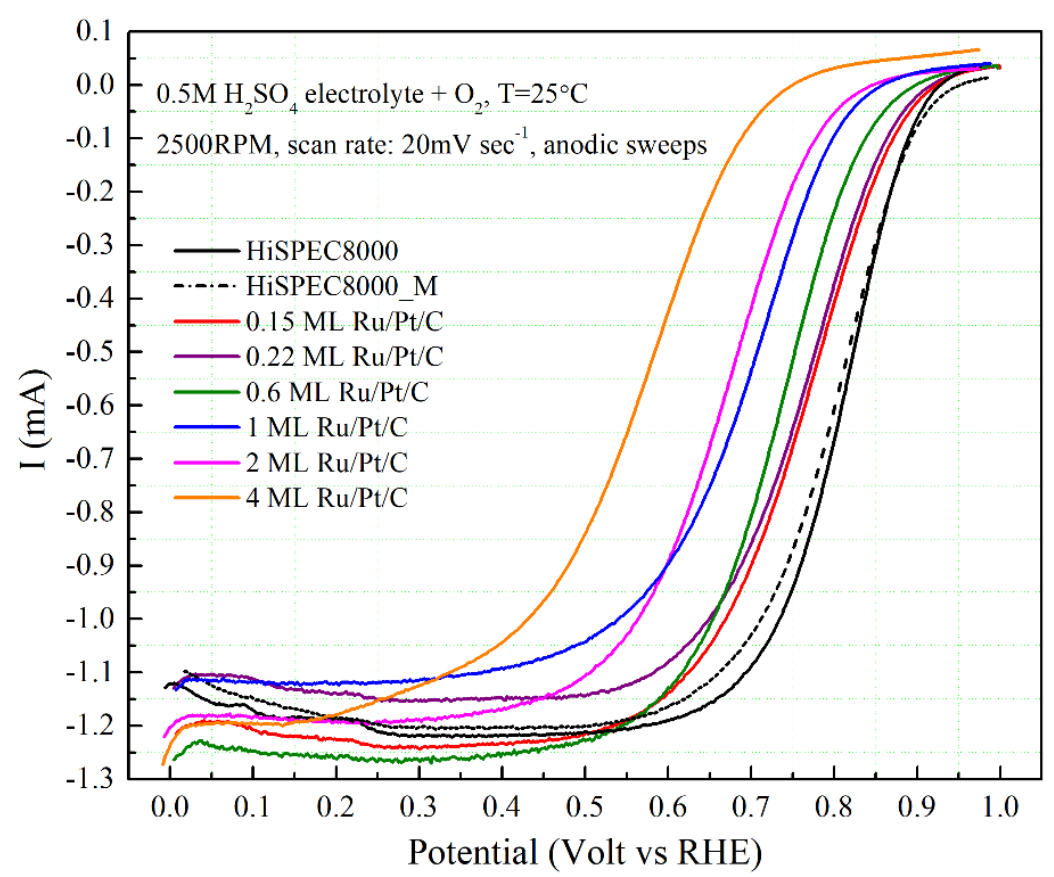

Figure 3 - RDE ORR polarization voltammograms of HiSPEC8000, HiSPEC8000_M and Ru-contaminated Pt/C catalysts. 


\begin{tabular}{|c|c|c|}
\hline \multicolumn{2}{|c|}{ Table II - ECSA and specific activities $\left(j_{k}^{0.85 V}\right)$ of the examined nanopowders } \\
\hline Catalyst & $\begin{array}{c}\text { ECSA } \\
{\left[\mathrm{m}^{2} \mathrm{~g}_{\mathrm{PtRu}}{ }^{-1}\right]}\end{array}$ & $\begin{array}{c}j_{k}^{0.85 V} \\
{\left[\mathrm{~A} \mathrm{~m}^{2} \mathrm{PtRu}^{-1}\right]}\end{array}$ \\
\hline HiSPEC8000 & $48 \pm 2$ & $2.6 \pm 0.1$ \\
\hline HiSPEC8000_M & $37 \pm 1$ & $2.6 \pm 0.1$ \\
\hline $0.15 \mathrm{ML} \mathrm{Ru} / \mathrm{Pt} / \mathrm{C}$ & $36 \pm 3$ & $1.4 \pm 0.1$ \\
\hline $0.22 \mathrm{ML} \mathrm{Ru} / \mathrm{Pt} / \mathrm{C}$ & $38 \pm 2$ & $1.2 \pm 0.1$ \\
\hline $0.6 \mathrm{ML} \mathrm{Ru} / \mathrm{Pt} / \mathrm{C}$ & $26 \pm 2$ & $0.9 \pm 0.1$ \\
\hline 1ML Ru/Pt/C & $42 \pm 2$ & $0.23 \pm 0.02$ \\
\hline 2ML Ru/Pt/C & $28 \pm 5$ & $0.05 \pm 0.01$ \\
\hline 4ML Ru/Pt/C & $22 \pm 2$ & $0.013 \pm 0.002$ \\
\hline
\end{tabular}

Assuming that the decrease in ORR activity is originating from the oxophilic nature of ruthenium that covers the platinum, we used DFT calculation of the binding energies of $\mathrm{O}$ and $\mathrm{OH}$ to estimate the $\mathrm{ORR}$ activity on model $\mathrm{Ru}_{\mathrm{n}} / \mathrm{Pt}(111)$ surfaces that represent Ru-contaminated Pt/C catalysts. The results of the DFT studies and their correlation to experimental results will be presented in the next sections.

\section{Theoretical study of ORR catalytic activity}

\section{Ruthenium coverage of platinum surface}

Initially, the surface energies of the clean $\mathrm{Ru}(0001)$ and $\mathrm{Pt}(111)$ surfaces were calculated. Our surface energy value for the $\mathrm{Ru}(0001)$ was found to be higher than that of the $\mathrm{Pt}(111)$ surface, that is $169 \mathrm{meV} / \mathrm{A}^{2}$ and $95 \mathrm{meV} / \mathrm{A}^{2}$, respectively, which is close to experimental data [53] and in agreement with other theoretical calculations from the literature $[54,55]$.

Next, the adsorption energy of $\mathrm{Ru}$ atoms at the clean $\mathrm{Pt}(111)$ was calculated. It was found that in the lowest-energy structure, ruthenium ad-atom binds to the hollow site on the $\mathrm{Pt}(111)$ surface, which corresponds to the ABCA Pt stacking. In addition, it was 
found that $\mathrm{Ru}_{n} / \mathrm{Pt}(111)$ structures with $n=2,4$ and 9 atoms, prefer planar bound structures on the $\mathrm{Pt}(111)$ surface. A detailed description of the different geometries of $\mathrm{Ru}_{n} / \operatorname{Pt}(111) \quad(n=1,2,4,9$ atoms $)$ and their adsorption energies can be found in Supplementary Material in Figures S2 and S3. It is known from the literature that there is formation of $\mathrm{Ru}$ monatomic layers at low coverages [56] and bilayer islands and three-dimensional clusters at higher levels of coverage [56-57]. Our surface cell was slightly too small to show the effect of multilayer formation and hence in our simulations, the ruthenium atoms typically tended to form a monolayer. A Bader charge analysis reveals that the $\mathrm{Ru}$ atoms tend to give some of their electrons to the Pt surface. For $\mathrm{Ru}_{1} / \mathrm{Pt}(111)$ we found that the $\mathrm{Ru}$ atom had a Bader charge of $+0.34 \mathrm{e}$. For the $\mathrm{Ru}_{2} / \mathrm{Pt}(111)$, the charge was $+0.29 \mathrm{e}$ per $\mathrm{Ru}$ atom (total of $+0.57 \mathrm{e}$ ), for $\mathrm{Ru} 4 / \mathrm{Pt}(111)$, the charge was +0.21 e per $\mathrm{Ru}$ atom (total of +0.85 ), and for full coverage of $\mathrm{Ru} 9 / \mathrm{Pt}(111)$ we found a charge of +0.11 e per $\mathrm{Ru}$ atom (total of +1.01 e for the $\mathrm{Ru}$ monolayer).

\section{O binding on $\operatorname{Ru} / \mathbf{P t}(111)$ surface}

As found previously [58-61], and also supported by us, the $\mathrm{O}$ atom has a greater tendency to bind on hollow sites on both the pristine $\operatorname{Pt}(111)$ and $\operatorname{Ru}(0001)$ surfaces. On the $\mathrm{Ru}_{\mathrm{n}} / \mathrm{Pt}(111)$ surfaces it was found that $\mathrm{O}$ atoms generally tend to bind on the $\mathrm{Ru}$ atoms, which can be explained by the stronger binding of $\mathrm{O}$ atom on the $\mathrm{Ru}(0001)$ (with calculated binding energy, $\mathrm{E}_{b}$, of $-5.97 \mathrm{eV}$ ) compared with that of binding on the $\operatorname{Pt}(111)$ (calculated $\mathrm{E}_{b}$ of $-4.25 \mathrm{eV}$ ). The lowest energy structures for $m \mathrm{O}$ on $\mathrm{Ru}_{n} / \mathrm{Pt}(111)$ surfaces are presented in Figure 4.

Since we examine the thermodynamic limit of lowest energy structures, the binding energy of a single oxygen atom will not be much affected by the Ru-atom coverage level, even if the coverage is one Ru atom per million Pt surface atoms, the oxygen 
would still tend to bind to the $\mathrm{Ru}$ atom. To fully account for an actual scenario, one needs to build a kinetic simulation which takes into account the adsorption on alternative surface sites. Here we use an alternative approach of saturating the surface with oxygen atoms. At some point, the next oxygen atom cannot bind to the Ru atom(s) and binds instead to a Pt surface atom, hence showing Ru-coverage-dependent behavior.

On the $\mathrm{Ru}_{1} / \mathrm{Pt}(111)$ one $\mathrm{O}$ atom binds $\mathrm{Ru}$ on-top site with a bond length ( $\mathrm{R}_{\mathrm{O}-\mathrm{Ru}}$ ) of 1.67 $\AA$, and then the second and the third $\mathrm{O}$ atoms tend to bind on this single Ru atom and also to Pt, with $\mathrm{R}_{\mathrm{O}-\mathrm{Ru}}$ of $1.77 / 1.80 \AA$ and $\mathrm{R}_{\mathrm{O}-\mathrm{Pt}}$ of $2.10 / 2.04 \AA$ for $2 \mathrm{O} / 3 \mathrm{O}$ atoms, respectively. The fourth $\mathrm{O}$ atom binds to the hollow site over $\mathrm{Pt}(111)$ with $\mathrm{R}_{\mathrm{O}-\mathrm{Pt}}$ of 2.04$2.05 \AA$.

A Bader charge $[62,63]$ analysis of $m \mathrm{O}$ on the $\mathrm{Ru}_{1} / \mathrm{Pt}(111)$ surface was performed. At $1 \mathrm{O} / \mathrm{Ru}_{1} / \mathrm{Pt}(111)$, the $\mathrm{Ru}$ atom has a charge of $+0.95 e$ and the charge of the $\mathrm{O}$ atom is $-0.60 e$, while at $2 \mathrm{O} / \mathrm{Ru}_{1} / \mathrm{Pt}(111)$, the charge redistribution (transfer) between $\mathrm{Ru}$ and $\mathrm{O}$ atoms is enhanced, i.e., the $\mathrm{Ru}$ atom has a larger positive charge, namely $+1.27 e$ and the charges on $\mathrm{O}$ atoms are $-0.68 e$ and $-0.61 e$. Following the trend, the charge on the $\mathrm{Ru}$ atom is increased to $+1.60 e$ at $3 \mathrm{O} / \mathrm{Ru}_{1} / \mathrm{Pt}(111)$ and the charges on the $\mathrm{O}$ atoms are $0.61 e,-0.68 e,-0.68 e$. Because of the saturation by $\mathrm{O}$ atoms, the fourth $\mathrm{O}$ atom in the $4 \mathrm{O} / \mathrm{Ru}_{1} / \mathrm{Pt}(111)$ has a charge of $-0.65 e$ and is adsorbed at a hollow site of the Pt surface (not near the $\mathrm{Ru}$ atom). 

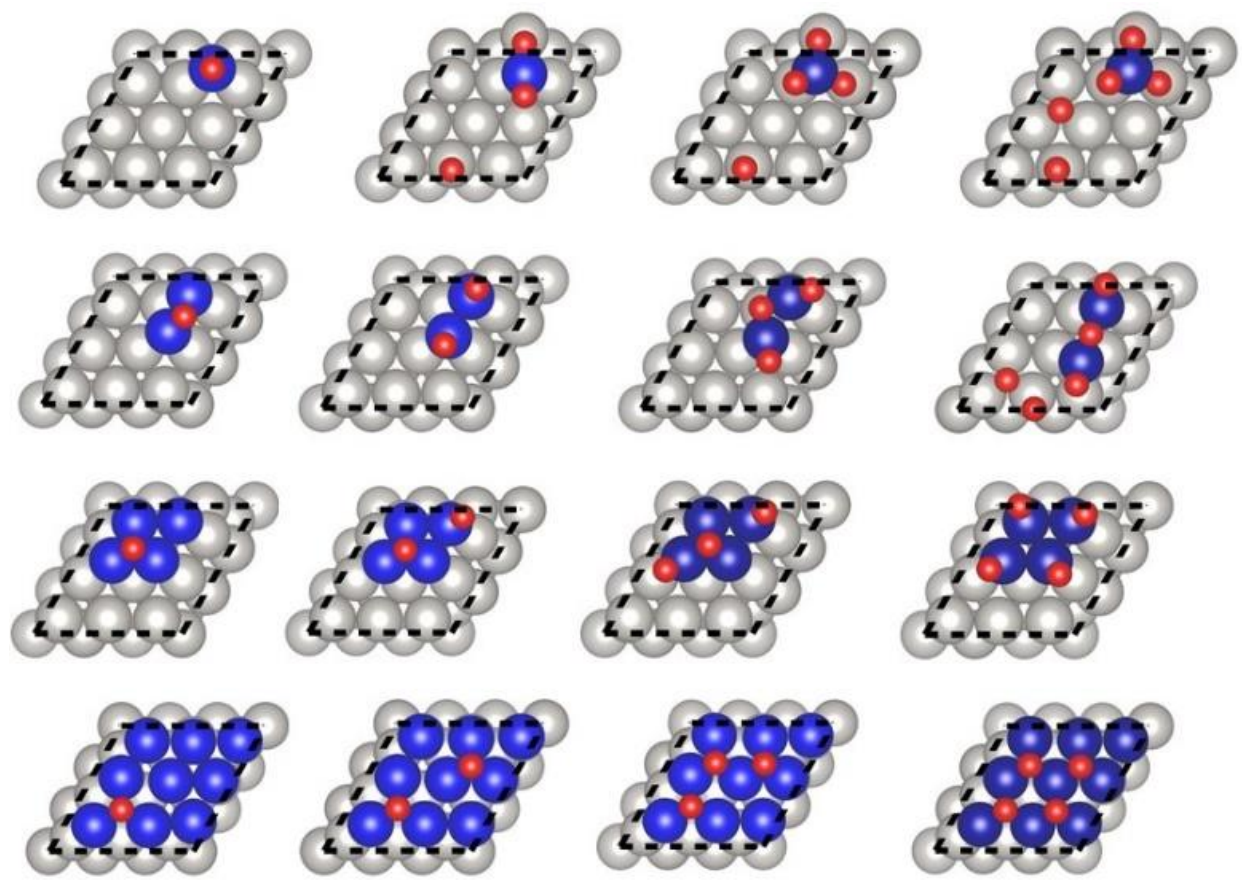

Figure 4 - The lowest energy structures for $m \mathrm{O}(m=1-4)$ atoms bound on

$\mathrm{Ru}_{n} \operatorname{Pt}(111)(\mathrm{n}=1,2,4,9)$ surfaces. $\mathrm{Pt}$ atoms are shown in gray, $\mathrm{Ru}$ atoms are shown in blue and oxygen atoms are shown in red.

For the adsorption of $\mathrm{O}$ atoms on the $\mathrm{Ru}_{n} / \mathrm{Pt}(111)$ ( $\mathrm{n}=2$ and 4), the following trend was observed. The more $\mathrm{Ru}$ atoms on the $\operatorname{Pt}(111)$ surface, and, hence, the more place for adsorption, the more $\mathrm{O}$ atoms tend to occupy the $\mathrm{Ru}$ bridge and then hollow $\mathrm{Ru}$ sites. On the $\mathrm{Ru}_{2} / \mathrm{Pt}(111), \mathrm{O}$ atoms bind on bridge and top sites for $1 \mathrm{O}$ and $2 \mathrm{O}$ atoms with $\mathrm{R}_{\mathrm{O}-\mathrm{Ru}}$ of $1.89 \AA$ and $1.67 \AA$, respectively. For $3 \mathrm{O}$ and $4 \mathrm{O}$ there is a mixture of two ontop and one O-bridge site bindings on $\mathrm{Ru}$, the fourth $\mathrm{O}$, for $4 \mathrm{O}$, binds on a hollow site over $\mathrm{Pt}(111)$. One of $\mathrm{O}$ in $4 \mathrm{O} / \mathrm{Ru}_{2} / \mathrm{Pt}(111)$ is on a $\mathrm{Pt}$ hollow site. One of the $\mathrm{O}$ atoms in the $1 \mathrm{O}, 2 \mathrm{O}$ and $3 \mathrm{O}$ structures on the $\mathrm{Ru} 4 / \mathrm{Pt}(111)$ is on a $\mathrm{Ru}$ hollow site, while the remaining $\mathrm{O}$ atoms are on-top $\mathrm{Ru}$ sites. For $4 \mathrm{O} / \mathrm{Ru}_{4} / \mathrm{Pt}(111)$ all $\mathrm{O}$ atoms bind to on-top $\mathrm{Ru}$ sites. The most energetically favorable binding sites for $\mathrm{O}$ are the hollow sites over $\mathrm{Ru}$ atoms for the case of $\mathrm{Ru}_{9} / \mathrm{Pt}(111)$ with $\mathrm{R}_{\mathrm{O}-\mathrm{Ru}}$ of 1.96-2.06 $\AA$. 


\section{OH binding on $\mathrm{Ru}_{n} / \mathrm{Pt}(111)$ surfaces}

The binding of $\mathrm{OH}$ species to the $\mathrm{Ru}_{n} / \mathrm{Pt}(111)$ surfaces follows trends similar to that of the binding of $\mathrm{O}$ atoms, namely, $\mathrm{OH}$ species first bind to $\mathrm{Ru}$ atoms and occupy all possible sites on these atoms. However, in addition, $\mathrm{OH}$ can also form hydrogen bonds with either other $\mathrm{OH}$ or surface atoms. This can further stabilize some surface-adsorbed structures. The structures for the $\mathrm{OH}$ binding on the $\mathrm{Ru}_{n} / \mathrm{Pt}(111)$ are presented in Figure S4 in Supplementary Material.

\section{Binding energies for $\mathrm{O}$ and $\mathrm{OH}$}

The binding energies $\left(\mathrm{E}_{b}\right)$ for $m \mathrm{O}$ and $m \mathrm{OH}(m=1-4)$ species on the clean $\mathrm{Pt}(111)$ and $\mathrm{Ru}(0001)$ surfaces, and on the $\mathrm{Ru}_{n} / \mathrm{Pt}(111)(\mathrm{n}=1,2,4,9)$ surfaces, are presented in Figure 5. For the pristine surfaces it was found that the $\mathrm{E}_{b}$ of a single $\mathrm{O}$ atom on $\mathrm{Pt}(111)$ is weaker than on $\mathrm{Ru}(0001):-4.25 \mathrm{eV}$ and $-5.97 \mathrm{eV}$, respectively, which is consistent with literature results $[56,59,64]$.

For the $\mathrm{Ru}_{\mathrm{n}} / \mathrm{Pt}(111)$ surfaces it is found that the oxygen binding energy, $\mathrm{E}_{\mathrm{b}}$, decreases with the number of adsorbed oxygen atoms. This trend is especially strong for the $\mathrm{Ru}_{1} / \mathrm{Pt}(111)\left(\mathrm{E}_{b}\right.$ decreases from $-5.86 \mathrm{eV}$ for a single oxygen to $-4.87 \mathrm{eV}$ with four oxygens) and $\mathrm{Ru}_{2} / \mathrm{Pt}(111)$ (from -6.21 to $-5.10 \mathrm{eV}$ ) surfaces. This can be explained by the saturation of $\mathrm{Ru}$ sites which forces some of the oxygen atoms to be adsorbed on $\mathrm{Pt}$ atoms and not on the $\mathrm{Ru}$ atoms. This decrease in $\mathrm{E}_{b}$ still exists but is less prominent for the case of $\mathrm{Ru} 9 / \mathrm{Pt}(111)\left(\mathrm{E}_{b}\right.$ changes from -6.35 to $\left.-5.92 \mathrm{eV}\right)$, where all the $\mathrm{O}$ atoms are uniformly distributed above the full-coverage $\mathrm{Ru}$ monolayer. Here, and also on the clean $\mathrm{Pt}(111)$ and $\mathrm{Ru}(0001)$ surfaces, another mechanism, of electrostatic repulsion between the adsorbed oxygen atoms, can explain the smaller decrease in the binding energy. 
The $\mathrm{E}_{b}$ for $\mathrm{mO}$ atoms on the $\mathrm{Ru}_{n} / \mathrm{Pt}(111)$ is stronger than on $\mathrm{Pt}(111)$ and closer to the $\mathrm{E}_{b}$ of $\mathrm{Ru}(0001)$. This finding can be related to the strain and ligand effects on the $\mathrm{Ru}_{n} / \mathrm{Pt}(111)$ systems, that play an important role in controlling the surface reactivity [65], and is in agreement with the experimentally known oxophilic nature of ruthenium (compared to platinum). For $\mathrm{Ru}_{4} / \mathrm{Pt}(111)$, the binding energy, $\mathrm{E}_{b}$, for $4 \mathrm{O}$ atoms approaches that of $\mathrm{Ru}(0001)$ because all the oxygen atoms tend to adsorb on $\mathrm{Ru}$ sites. However, it is statistically possible that one or more of the $\mathrm{O}$ atoms can also bind to $\mathrm{Pt}$ atoms at a higher energy state. We therefore considered an additional higher energy structure, defined as $\mathrm{Ru}_{4} / \mathrm{Pt}(111)^{*}$, where one of the $\mathrm{O}$ atoms is adsorbed on the $\mathrm{Pt}$ surface and not on the $\mathrm{Ru}_{4}$ cluster.

The $\mathrm{E}_{b}$ for $\mathrm{OH}$ species shows a trend similar to that of the $\mathrm{E}_{b}$ of $\mathrm{O}$ atoms, except for the case of $4 \mathrm{OH} / \mathrm{Ru}_{n} / \mathrm{Pt}(111)$, in which we found a stronger binding of $4 \mathrm{OH}$ relative to $3 \mathrm{OH}$ on most surfaces. This can be explained by the contribution of the hydrogen bonds between the hydrogen and $\mathrm{Pt} / \mathrm{Ru}$ atoms on these surfaces.
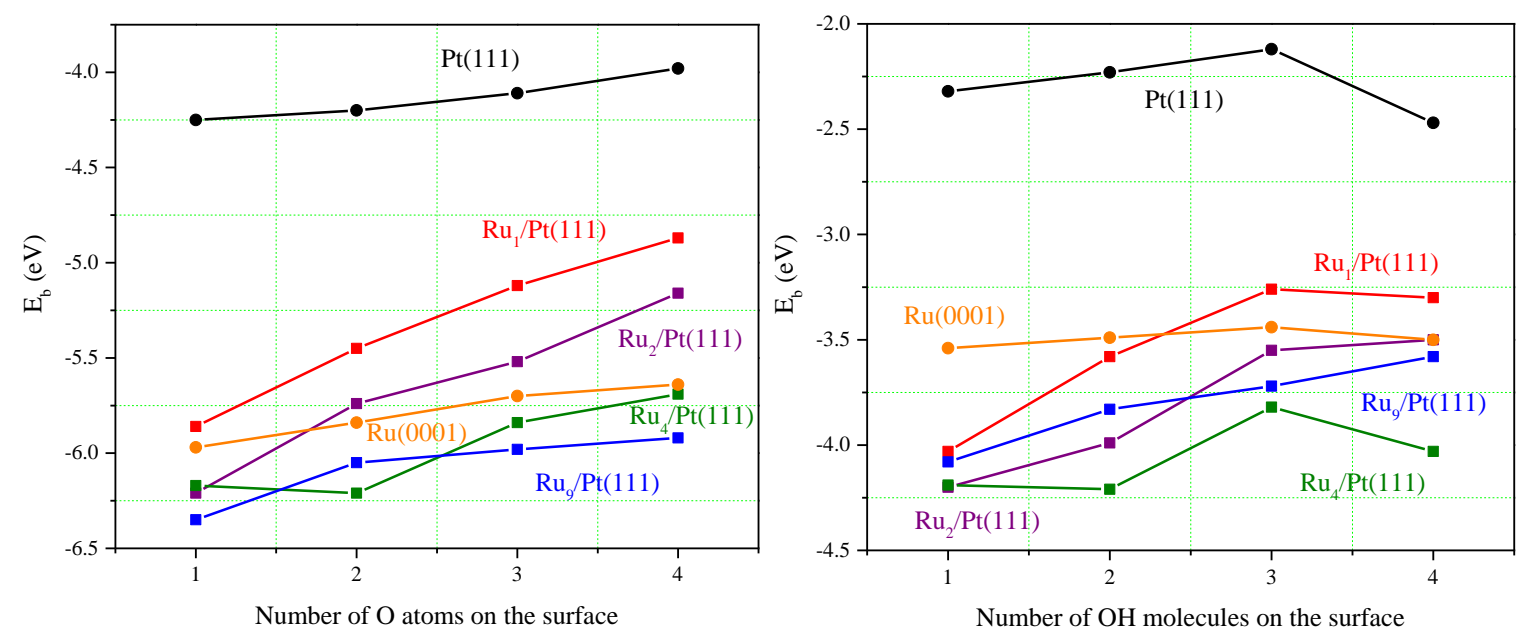

Figure 5 - Binding energies $\left(\mathrm{E}_{b}\right)$ for $m \mathrm{O}$ atoms and $m \mathrm{OH}$ species $(m=1-4)$ on the $\mathrm{Ru}_{n} / \mathrm{Pt}(111)$ ( $n=1,2,4,9)$. Here, the black, orange, red, violet, green and blue lines correspond to the cases of $\mathrm{Pt}(111), \mathrm{Ru}(0001), \mathrm{Ru}_{1} \operatorname{Pt}(111), \mathrm{Ru}_{2} \mathrm{Pt}(111), \mathrm{Ru}_{4} \mathrm{Pt}(111)$ and $\mathrm{Ru} \mathrm{u}_{9} \mathrm{Pt}(111)$, respectively. 


\section{Estimated ORR activity of $\operatorname{Ru}_{n} / \operatorname{Pt}(111)$ surfaces}

The ORR activity was estimated by calculating $\Delta \mathrm{G}_{0}\left(\mathrm{U}_{0}\right), \Delta \mathrm{G}_{2}\left(\mathrm{U}_{0}\right)$, and $\Delta \mathrm{G}_{1}\left(\mathrm{U}_{0}\right)$, and estimating the minimum as described in Equation 13. Results for single $\mathrm{O} / \mathrm{OH}$ adsorption and for 4O/OH adsorption are shown in Tables SI and SII in Supplementary Material. The results for the calculated activity as a function of $\Delta E_{O}$ and $\Delta E_{O H}$ for the case of $4 \mathrm{O}$ atoms and $4 \mathrm{OH}$ species are shown in Figure 6. This figure also includes an estimated activity for the higher energy structure $\mathrm{Ru}_{4} / \mathrm{Pt}(111)^{*}$ for which $3 \mathrm{O} / \mathrm{OH}$ species are adsorbed on $\mathrm{Ru}$ sites and one $\mathrm{O} / \mathrm{OH}$ is adsorbed on $\mathrm{Pt}(111)$. This structure can be considered as more representative of a real-world situation compared to the lowest energy case where all species are adsorbed on the $\mathrm{Ru}$ atoms and none on the platinum. It can be seen that for both single O/OH (Fig. S5 in Supplementary Material) and 4O/OH (Figure 6 and Figure S6 in Supplementary Material) the addition of Ru atoms is followed by a decrease in $\Delta E_{O}$ and $\Delta E_{O H}$ (i.e., increased binding of $\mathrm{O}$ and $\mathrm{OH})$ that leads to a decrease in ORR activity. It is also evident from Figures S5 and S6, that the effect of Ru coverage on $\Delta E_{O}, \Delta E_{O H}$ and the estimated ORR activity is more pronounced for the case of $4 \mathrm{O} / \mathrm{OH}$. The reason for this is that a single $\mathrm{O} / \mathrm{OH}$ will always have an available $\mathrm{Ru}$ site to adsorb on, while in the case of $4 \mathrm{O} / \mathrm{OH}$, the $\mathrm{Ru}$ sites become saturated at low $\mathrm{Ru}$ coverages. 


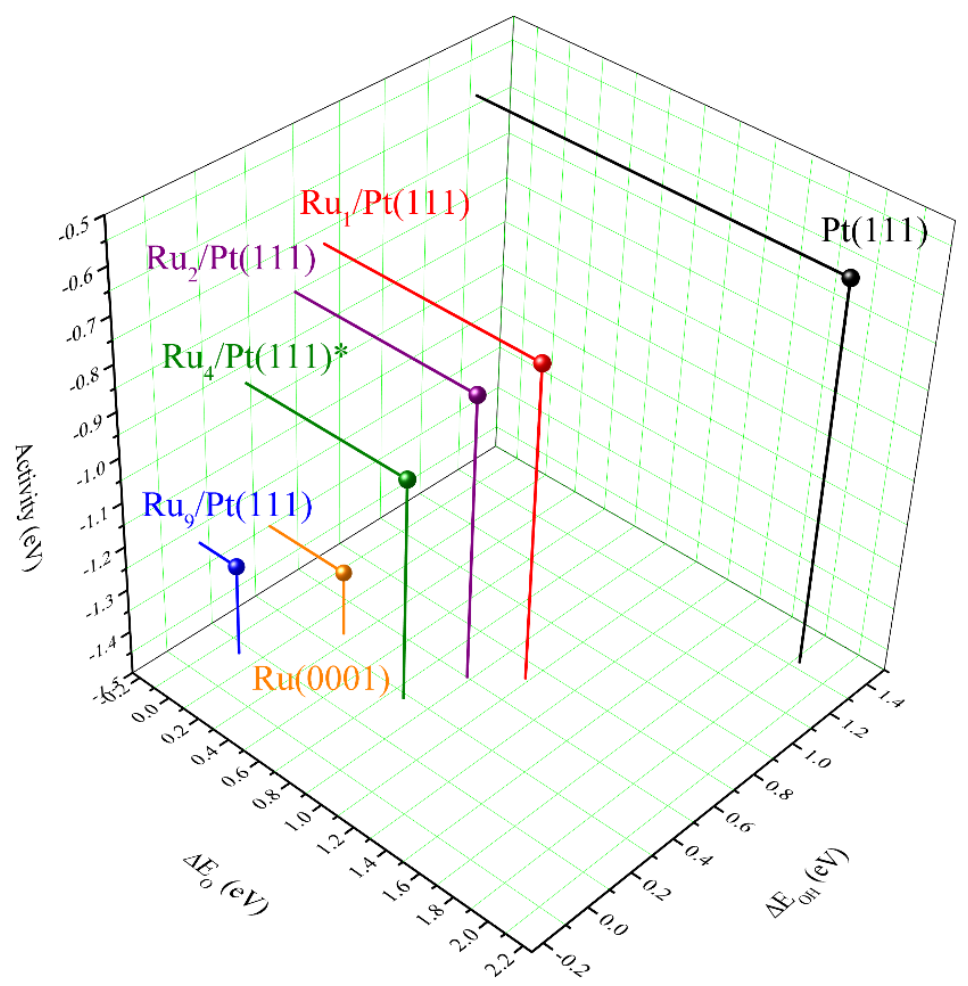

Figure 6 - Estimated ORR activity $A$ (according to Eq. 6) as a function of $\Delta E_{O}$ and $\Delta E_{O H}$. These data are for the adsorption of four oxygen atoms and an $\mathrm{OH}$ species. Here, the presented data correspond to the lowest energy structures of $\operatorname{Pt}(111)$, $\mathrm{Ru}_{1} / \operatorname{Pt}(111), \mathrm{Ru}_{2} / \operatorname{Pt}(111), \mathrm{Ru}_{9} / \operatorname{Pt}(111), \mathrm{Ru}(0001)$, and a higher-energy structure of $\mathrm{Ru}_{4} / \operatorname{Pt}(111), \mathrm{Ru}_{4} / \operatorname{Pt}(111)^{*}$, which represents a more probable real-world structure. Figure S6 in Supplementary Material contains the data for the lowest-energy structure of $\mathrm{Ru}_{4} / \mathrm{Pt}(111)$.

\section{Analysis of ruthenium effect on ORR}

The DFT calculations presented above clearly show that indeed the oxophilic nature of ruthenium (compared to platinum), that manifests itself in increased $\mathrm{O}$ and $\mathrm{OH}$ binding, is the root cause of the inferior ruthenium ORR activity at potentials relevant to PEMFC. According to the Sabatier principle, too-strong binding of $\mathrm{O}$ and $\mathrm{OH}$ on ruthenium (compared to platinum) reduces the possibility of $\mathrm{O}$ and $\mathrm{OH}$ hydrogenation that is needed in order to complete $\mathrm{O}_{2}$ reduction to $\mathrm{H}_{2} \mathrm{O}$. Moreover, because of its 
oxophilic nature, ruthenium is oxidized at much lower potentials compared to platinum. Hence, at PEM-cathode operating potentials ruthenium is oxidized, cannot adsorb $\mathrm{O}_{2}$ molecules and facilitate their reduction. Besides being effectively ORR-inactive, ruthenium deposited on platinum (as in the case of Ru-contaminated platinum studied here) masks three platinum atoms, preventing them from adsorbing $\mathrm{O}_{2}$ molecules and effectively reducing the available platinum sites (i.e., available surface area) for ORR. Figures $7 \mathrm{a}$ and $7 \mathrm{~b}$ exhibit the estimated and experimental ORR activity as a function of $\mathrm{Ru}$ coverage. It can be seen that for both theoretical and experimental methods the addition of $\mathrm{Ru}$ atoms leads to a decrease in ORR activity. Although expressed in different units, qualitatively similar trends can be seen in both figures, validating the use of $\mathrm{O}$ and $\mathrm{OH}$ binding energies for the estimation of ORR activity.

In Figure $7 b$ it can be seen that the deposition of a 0.15 equivalent monolayer of ruthenium $(0.15 \mathrm{ML} \mathrm{Ru} / \mathrm{Pt})$ resulted in a decrease of $\sim 45 \%$ of ORR activity. Given the explanation presented above, attributing the decrease of ORR activity to the coverage of three platinum atoms by a single ORR-inactive ruthenium atom, and the clear presence of platinum features on the voltammogram of $0.15 \mathrm{ML} \mathrm{Ru} / \mathrm{Pt}$, the massive decrease in ORR activity is quite surprising, i.e., a less severe decrease in ORR activity can be expected. Moreover, additional deposition of ruthenium, up to 0.22 and 0.6 equivalent monolayers $(0.22 \mathrm{ML} \mathrm{Ru} / \mathrm{Pt}$ and $0.6 \mathrm{ML} \mathrm{Ru} / \mathrm{Pt})$ hasn't resulted in such a drastic decrease in ORR activity; the ORR activity decreased by $\sim 20 \%$ when the equivalent monolayer was increased from 0.15 to 0.22 and from 0.22 to 0.6 . Further deposition of ruthenium to 1,2 and 4 equivalent monolayers (1ML Ru/Pt, 2ML Ru/Pt and $4 \mathrm{ML} \mathrm{Ru} / \mathrm{Pt}$ ) leads to a saturation in ORR activity decrease. A question arises regarding the reason for this behavior of ORR activity, that appears to exhibit a exponential-like decay with increased ruthenium coverage (as demonstrated by 
exponential decay fit in Figure 7b). In order to answer this question, it is necessary to examine the mechanism of $\mathrm{O}_{2}$ reduction on a platinum surface and the preferred deposition of Ru sub-monolayers on Pt surfaces.

Although ORR is a multistep reaction with a quite complex mechanism that is still somewhat in debate $[21,66,67]$, the breaking of an $\mathrm{O}-\mathrm{O}$ bond (i.e., $\mathrm{O}_{2}$ dissociation) and the formation of $\mathrm{O}-\mathrm{H}$ bonds [66] involving a four-electron process must occur in order to achieve a complete reduction of $\mathrm{O}_{2}$. Among multiple possible configurations for $\mathrm{O}_{2}$ adsorption on a platinum surface, adsorption on two adjusted platinum sites (the socalled bridge side-on) is generally favored for the promotion of $\mathrm{O}_{2}$ dissociation $[68,69]$. As mentioned above, ruthenium adsorbed on platinum masks three platinum sites, preventing those sites from adsorbing $\mathrm{O}_{2}$ in any configuration. We shall name this type of platinum deactivation a direct deactivation. Nine platinum sites surrounding the masked three platinum sites lose some of their potential neighbors for bridge side-on adsorption. This may lead to increased probability for $\mathrm{O}_{2}$ adsorption in a less favorable configuration for $\mathrm{O}_{2}$ dissociation and thus negatively affecting ORR kinetics. We shall name this type of deactivation an indirect deactivation. Hence, one ruthenium atom has the potential to deactivate to some degree, twelve atoms of platinum and not only three atoms. We believe this to be the reason for the massive decrease in the ORR activity for $0.15 \mathrm{ML} \mathrm{Ru} / \mathrm{Pt}$.

We shall now turn our attention to the deposition of ruthenium sub-monolayers on platinum surfaces. As was mentioned previously, ruthenium deposition on platinum has a tendency to create monolayer clusters at low coverages and bilayer islands and threedimensional clusters at higher coverages (Volmer-Weber growth). It is likely that for 0.22 and 0.6 equivalent monolayers such islands will be formed, hence effectively reducing the number of platinum sites deactivated by each ruthenium atom and 
reducing the decrease rate in ORR activity with increased ruthenium deposition. Additional reduction of deactivated platinum sites for each ruthenium atom (and subsequent reduction in ORR activity decrease rate) is expected as a result of the overlap between the deactivated platinum sites. It is reasonable to assume that such overlap will occur at sufficiently high ruthenium coverage and will grow as ruthenium coverage is increased until the ORR activity will reach a plateau value that is similar to the ORR activity of ruthenium. We believe that the proposal described above provides an explanation for the observed exponential-like decay of ORR activity on $\mathrm{Ru}-$ contaminated $\mathrm{Pt} / \mathrm{C}$.

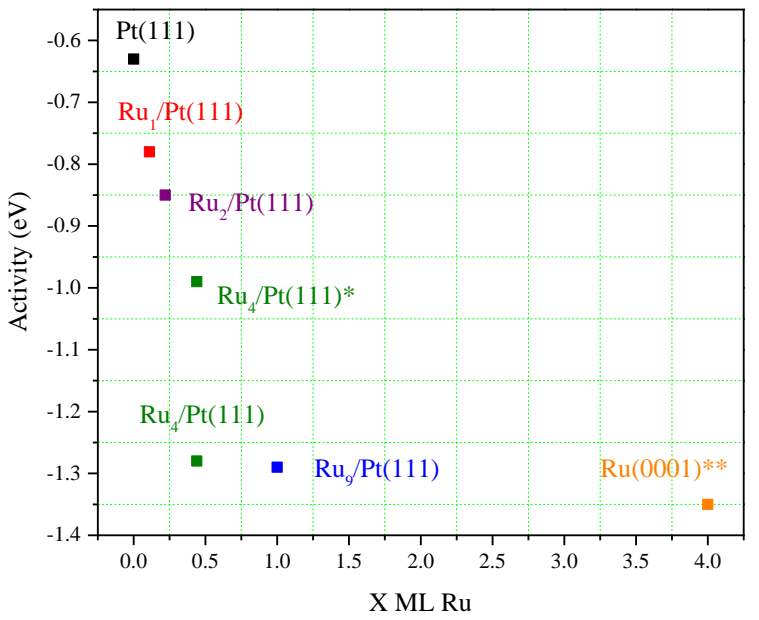

(a)

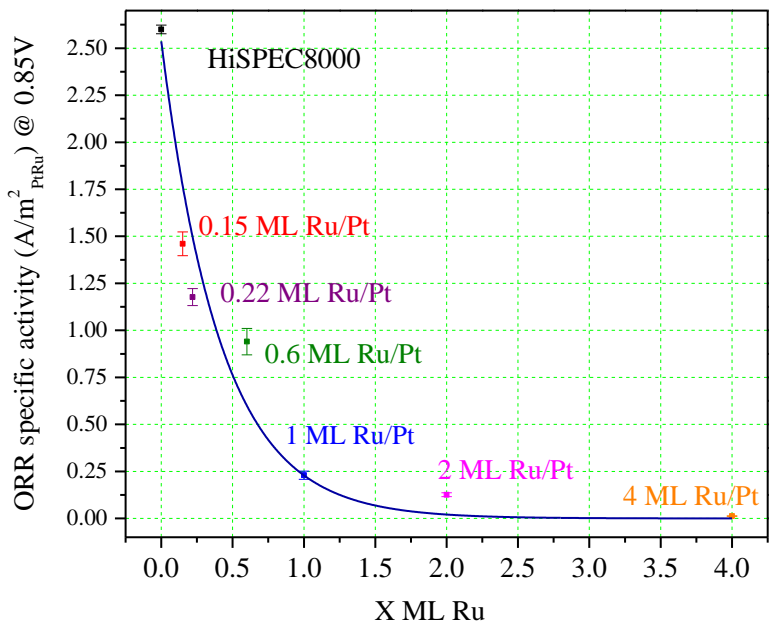

(b)

Figure 7 - (a) Estimated ORR activity according to Equation 6 and (b) experimentally measured activity as a function of ruthenium coverage. An exponential decay fit (blue line) is used to demonstrate the exponential-like decay of experimentally measured activity with increasing ruthenium coverage. Estimated activities were calculated for the lowest energy structures, except for $\mathrm{Ru}_{4} / \operatorname{Pt}(111)^{*}$, for which both the lowest-energy and a higher-energy and more realistic structure were used (see explanation in the text). **The $\mathrm{Ru}(0001)$ surface was used to simulate the case of a $4 \mathrm{ML} \mathrm{Ru}$ coverage. 


\section{Implications of ruthenium contamination on the performance of reformate-based} PEMFCs and DMFCs

Even though RDE ORR experiments cannot precisely predict an FC cathode polarization, they can be used to obtain a first-order approximation of it. Hence, the RDE ORR polarization data obtained during this research can be used to assess the overpotential penalty of an FC cathode originating from ruthenium contamination.

To assess the added overpotential, we shall look at Figure 8, which presents masstransport, background and iR-corrected Tafel plots for HiSPEC8000 and 0.15ML $\mathrm{Ru} / \mathrm{Pt}$. The latter was chosen because of the similarity of its ruthenium content to ruthenium contamination found by Piela et al. [12]. In order to approximate the overpotential, we compare the potentials of both RDEs at the same current densities that polarize the RDEs to typical potential ranges of DMFC and PEMFC cathodes during FC operation. The catalyst loadings on RDEs for both catalysts were similar, $\sim 20 \mu \mathrm{g}_{\mathrm{PGM}} \mathrm{cm}_{\text {geo }^{-2}}$, hence any overpotential for $0.15 \mathrm{ML} \mathrm{Ru} / \mathrm{Pt}$ can be associated with ruthenium contamination.

Looking at the potential range typical to operating DMFC cathode, $\sim 0.8 \mathrm{~V}$ $[70,71,72,73]$, it can be seen that the approximated overpotential penalty (marked as $\eta_{\mathrm{Ru}}$ at Figure 8 ) for $0.15 \mathrm{ML} \mathrm{Ru} / \mathrm{Pt}$ is roughly $45 \mathrm{mV}$. Assuming a cell voltage of $0.45 \mathrm{~V}$ during DMFC operation, this penalty will translate to roughly $10 \%$ decrease in power density. The overpotential penalty grows to roughly $75 \mathrm{mV}$ over a potential range typical to an operating PEMFC cathode, $\sim 0.65 \mathrm{~V}$. Taking into account the small overpotential of a PEMFC anode and assuming a cell voltage of $0.6 \mathrm{~V}$ during operation, we can approximate the penalty in power density at slightly more than $10 \%$. 


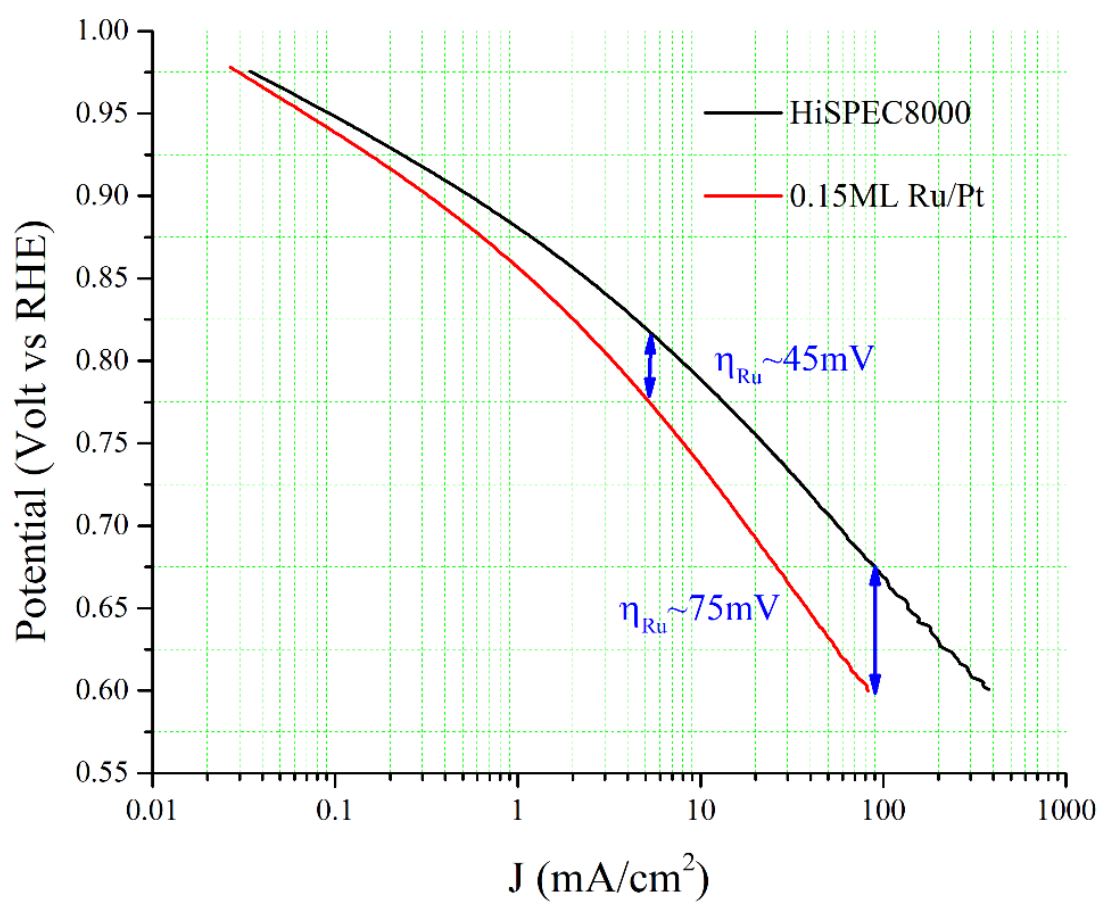

Figure 8 - Tafel plots for oxygen reduction on HiSPEC8000 and 0.15ML Ru/Pt. The plots were produced with the use of RDE ORR polarization voltammograms shown in Figure 3 following mass-transport, background and iR corrections.

\section{Conclusions}

In this work we studied the effect of ruthenium contamination on ORR on platinum, focusing on the implications on PEMFC and DMFC cathode-relevant potentials. To obtain our objective, a commercial $50 \% \mathrm{Pt} / \mathrm{C}$ catalyst was contaminated by precisely known amounts of ruthenium. The contamination range varied from relatively low contamination, equivalent to $0.15 \mathrm{ML}$ of ruthenium, to severe contamination, equivalent to $4 \mathrm{ML}$ of ruthenium.

The contaminated catalysts were examined with the use of physico-chemical methods to verify and quantify ruthenium contamination. It was found that ruthenium was 
deposited on the surface of platinum nanoparticles in a core-shell-like structure without creating separate ruthenium nanoparticles on the carbon support.

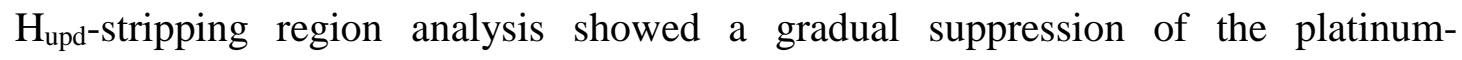
characteristic hydrogen region that was correlated with increased ruthenium coverage of the platinum. While $\mathrm{H}_{\text {upd-stripping peaks from (110) and (100) platinum planes could }}$ be seen for $0.15 \mathrm{ML} \mathrm{Ru} / \mathrm{Pt}$, only small remnants of platinum-characteristic features could be seen for $1 \mathrm{ML} \mathrm{Ru} / \mathrm{Pt}$, while higher ruthenium contamination showed ruthenium-characteristic features.

RDE ORR polarization showed the negative effect of ruthenium on ORR at potentials relevant to the PEMFC/DMFC cathode, exhibiting a progressive shift of onset potentials and mixed-kinetics/mass-transport regions toward more negative potentials and decrease of ORR specific activity with increasing contamination of ruthenium. However, in contrast to gradual changes in $\mathrm{H}_{\text {upd }}$ features, ORR specific activity showed a drastic $\sim 45 \%$ decrease already for $0.15 \mathrm{ML} \mathrm{Ru} / \mathrm{Pt}$ and, in general, a pseudoexponential decay with increased ruthenium coverage.

With the use of our DFT studies and previously published experimental results [20], we showed that the negative effect of ruthenium on ORR could be attributed to the masking of platinum sites by adsorbed ruthenium atoms, as well as to the oxophilic nature of ruthenium, that was found to bind $\mathrm{O}$ and $\mathrm{OH}$ much more strongly than platinum, reducing its effectiveness in ORR catalysis. Potentially unfavorable configuration of $\mathrm{O}_{2}$ adsorption on platinum sites that immediately surround the ruthenium-masked platinum sites, the formation of bilayer islands and three-dimensional clusters and overlap between the deactivated platinum sites were proposed as a possible explanation for the exponential-like decay of ORR on ruthenium-contaminated catalysts. 
The results of this research stress the negative impact of ruthenium dissolution from the anode and its crossover to the cathode in reformate-based PEMFCs and DMFCs. The dramatic reduction in ORR activity - almost 50\% - and the subsequent reduction in power density that accompanied the smallest ruthenium contamination, emphasizes the need for development of PtRu catalysts with higher stability, Ru-pre-leaching procedures during catalyst/GDE/MEA preparation and control of anode potential during FC operation in order to avoid or at least to reduce the performance penalty caused by ruthenium crossover.

\section{Acknowledgements}

DK and EP wish to thank the Pazy Foundation for financial support for this research (Grant No. 289/2017). AN would like to thank the Planning \& Budgeting Committee of the Council of High Education and the Prime Minister Office of Israel, in the framework of the INREP project.

\section{References:}

${ }^{1}$ S. Gottesfeld, T. A. Zawodzinski, Polymer Electrolyte Fuel Cells. In: Alkire RC, Kolb DM (eds) Advances in Electrochemical Science and Engineering, vol 5. Wiley-VCH, Weinheim, pp 195-301 (1997).

${ }^{2}$ R. Borup, J. Meyers, B. Pivovar, Y. S. Kim, R. Mukundan, N. Garland, D. Myers, M. Wilson, F. Garzon, D. Wood, P. Zelenay, K. More, K. Stroh, T. A. Zawodzinski, J. Boncella, J. E. McGrath, M. Inaba, K. Miyatake, M. Hori, K. Ota, Z. Ogumi, S. Miyata, A. Nishikata, Z. Siroma, Y. Uchimoto, K. Yasuda, K. I. Kimijima, N. Iwashita, Chem Rev. 107, 3904 -3951 (2007).

${ }^{3}$ K. Shah, R.S. Besser, Journal of Power Sources 166, 177-193 (2007).

${ }^{4}$ R. C. Urian, A. F. Gulla, and S. Mukerjee, J. Electroanal. Chem. 307, 554-555 (2003)

${ }^{5}$ A. Pozio, R. F. Silva, M. De Francesco, F. Cardellini, L. Giorgi, Electrochim. Acta, 48, 1625 (2003).

${ }^{6}$ M. Watanabe, S. Motoo, J. Electroanalytical Chemistry and Interfacial Electrochemistry 60, 267-273 (1975).

${ }^{7}$ M. Watanabe, S. Motoo, J. Electroanalytical Chemistry and Interfacial Electrochemistry 60, 275-283 (1975). 
${ }^{8}$ E. Antolini, J. Solid State Electrochem., 15(3) 455-472 (2010).

${ }^{9}$ P. Jovanovič, V. S. Šelih, Martin Šala, S. Hočevar, F. Ruiz-Zepeda, N. Hodnik, M. Bele, M. Gaberšček, Electrochimica Acta, 211, 851-859 (2016).

${ }^{10}$ L. Gancs, N. Hakim, B. N. Hult, and S. Mukerjee, ECS Transactions, 3 (1), 607-618 (2006)

${ }^{11}$ N. Cabello - Morenoa, E. M. Crabb, J. M. Fisher, A. E. Russell, D. Thompsett, ECS Transactions, 16(2), 483-496 (2008).

${ }^{12}$ P. Piela, C. Eickes, E. Brosha, F. Garzon, P. Zelenay. J. Electrochem. Soc., 151(12), A2053 (2004).

13 A. Schoekel, J. Melke, M. Bruns, K. Wippermann, F. Kuppler, C. Roth, Journal of Power Sources 301, 210-218 (2016)

${ }^{14}$ N.A. Anastasijević, Z.M. Dimitrijević, R.R.Adzic, Electrochemica Acta, 31(9), 1125-1130 (1986).

${ }^{15}$ M. Metikoš-Huković, R. Babić, F. Jović, Z. Grubač, Electrochimica Acta, 51(7), 1157-1164 (2006).

${ }^{16}$ D. Cao, A. Wieckowski, J. Inukai, N. Alonso-Vante, J. Electrochem. Soc., 153(5), A869 -A874 (2006).

${ }^{17}$ V. Stamenkovic, B. N. Grgur, P. N. Ross, and N. M. Markovic, J. Electrochem. Soc., 152(2), A277A282 (2005).

${ }^{18}$ D. Kaplan, M. Goor, M. Alon, S. Tsizin, L. Burstein, Y. Rosenberg, I. Popov, E. Peled. J Power Sources 306, 219-225 (2016).

${ }^{19}$ L. Yang, M. B. Vukmirovic, D. Su, K. Sasaki, J. A. Herron, M. Mavrikakis, S. Liao, R. R. Adzic, J. Phys. Chem. C 117, 1748-1753 (2013).

${ }^{20}$ L. Gancs, B. N. Hult, N. Hakim, S. Mukerjee, Electrochem. Solid-State Lett. 10, 9, B150 (2007).

${ }^{21}$ J. K. Nørskov, J. Rossmeisl, A. Logadottir, and L. Lindqvist, J. R. Kitchin, T. Bligaard, H. Jonsson, J. Phys. Chem. B 108, 17886-17892 (2004).

${ }^{22}$ L. Clare, A. Kucernak, J. Phys. Chem. B 106, 1036 (2002).

${ }^{23}$ D. Kaplan, L. Burstein, I. Popov, E. Peled, Journal of The Electrochemical Society, 163 (9) F1004F1010 (2016).

${ }^{24}$ K. Shinozaki, J. W. Zack, R. M. Richards, B. S. Pivovar, S. S. Kocha, Journal of The Electrochemical Society 162 (10) F1144-F1158 (2015).

${ }^{25}$ N. Hodnik, P. Jovanovič, A. Pavlišič, B. Jozinović, M. Zorko, M. Bele, V. S. Šelih, M. Šala, S. Hočevar, M. Gaberšček, J. Phys. Chem. C 119, 10140-10147 (2015).

${ }^{26}$ H. A. Gasteiger, N. Markovic, P. N. Ross, Jr E. J. Cairns, J. Phys. Chem. 97, 12020 (1993).

${ }^{27}$ I. Takahashi, S. S. Kocha, Journal of Power Sources 195, 6312-6322 (2010).

${ }^{28}$ Y. Garsany, I.L. Singer, K.E. Swider-Lyons, Journal of Electroanalytical Chemistry 662(2), 396 406 (2011).

${ }^{29}$ K. Shinozaki, J.W. Zack, S. Pylypenko, B.S. Pivovar, S.S. Kocha, Journal of The Electrochemical Society 162(12), F1384-F1396 (2015).

${ }^{30}$ F. Nart, W. Vielstich, Handbook of Fuel Cells - Fundamentals, Technology and Applications, Ch. 21, Vol. 2, edited by W. Vielstich, H. A. Gasteiger, A. Lamm, John Wiley \& Sons, Ltd (2010).

${ }^{31}$ S. S. Kocha, Y. Garsany, D. Myers (2013) Testing Oxygen Reduction Reaction Activity with the Rotating Disc Electrode Technique DOE webinar energy.gov/eere/fuelcells/webinar-testing-oxygenreduction-reaction-activity-rotating-disc-electrode-technique, 
http://energy.gov/sites/prod/files/2014/03/f12/webinarslides_rde technique_031213.pdf, accessed at $12 / 05 / 2020$

${ }^{32}$ D. Kaplan, L. Burstein, I. Popov, E. Peled, Journal of The Electrochemical Society, 163(9) F1004F1010 (2016).

${ }^{33}$ D. Kaplan, M. Goor, L. Burstein, I. Popov, M. Shviro, E. Peled. Journal of Solid State Electrochemistry 24, 2385-2393 (2020).

${ }^{34}$ D. Durst, C. Simon, F. Hasché, H.A. Gasteiger, Journal of The Electrochemical Society 162(1), F190-F203 (2015).

${ }^{35}$ P. E. Blöchl, Projector augmented-wave method. Phys Rev. B 50(24), 17953-17979 (1994).

${ }^{36}$ G. Kresse, G. Jouber, Phys Rev B - Condens Matter Mater Phys 59(3), 1758-1775 (1999).

${ }^{37}$ G. Kresse, J. Furthmüller, Phys. Rev. B 54(16), 11169-11186 (1996).

${ }^{38}$ H. Jürgen, J. Comput Chem 29, 2044-2078 (2008).

${ }^{39}$ C. E. Calderon, J. J. Plata, C. Toher, C. Oses, Ohad Levy, M. Fornari, A. Natan, M. J. Mehl, G. Hart, M. B. Nardelli, S. Curtarolo, Comp. Mat. Sci. 108, 233-238 (2015).

${ }^{40}$ J. L. F. Da Silva, C. Stampfl, M. Scheffler, Surf. Sci. 600, 703- 715 (2006).

${ }^{41}$ P. Haas, F. Tran, P. Blaha, Phys. Rev. B 79, 085104 (2009).

${ }^{42}$ W. Davey, Phys. Rev. 25 (6), 753-761 (1925).

${ }^{43}$ C. Kittel, Introduction to Solid State Physics, 7th ed.; John Wiley \& Sons: New York, 1996

${ }^{44}$ C. Stampfl, M. Scheffler. Phys. Rev. B 54 (4), 2868 (1996).

${ }^{45}$ Physics of Solid Surfaces: Electronic and Vibrational Properties, edited by G. Chiarotti, LandoltBornstein, New Series, GroupIII, Vol. 24, Pt. Springer-Verlag, Berlin, 1994.

${ }^{46}$ K. Mathew, R. Sundararaman, K. Letchworth-Weaver, T. A. Arias, and R. G. Hennig, J. Chem. Phys. 140, 084106 (2014).

${ }^{47}$ K. Mathew, V. S. C. Kolluru, S. Mula, S. N. Steinmann, R. G. Hennig. J. Chem. Phys. 151, 234101 (2019).

${ }^{48}$ J. K. Nørskov, T. Bligaard, A. Logadottir, S. R. Bahn, L. B. Hansen, M. V. Bollinger, H. S. Bengaard, B. Hammer, Z. Sljivancanin, M. Mavrikakis, Y. Xu, S. Dahl, C. J. H. Jacobsen, J. Catal. 209, 275 (2002).

${ }^{49}$ Q. Deng, J. Zhao, T. Wu, G. Chen, H. A. Hansen, T. Vegge. Journal of Catalysis 370, 378-384 (2019)

${ }^{50}$ T. T. H. Cheng, N. Jia, P. He, Journal of The Electrochemical Society 157(5), B714-B718 (2010).

${ }^{51}$ J.P. Zheng, P.J. Cygan, T.R. Jow, Journal of The Electrochemical Society 142(8), 2699-2703 (1995).

${ }^{52}$ F. Richarz, B. Wohlmann, U. Vogel, H. Hoffschulz, K. Wandelt, Surface Science 335, 361-371 (1995).

${ }^{53}$ W. R. Tyson, W.A. Miller, Surface Science 62, 267-276 (1977).

${ }^{54}$ L. Vitos, A. V. Ruba, H. L. Skriver, J. Kollar, Surface Science 411, 186-202 (1998).

${ }^{55}$ N. E. Singh-Miller, Nx. Marzari, Phys. Rev. B 80, 235407 (2009).

${ }^{56}$ W. F. Lin, M. S. Zei, M. Eiswirth, G. Ertl, T. Iwasita, W. Vielstich, J. Phys. Chem. B 103, 69686977 (1999). 
${ }^{57}$ J. S. Spendelow, P.K. Babu, A. Wieckowski, Current Opinion in Solid State and Materials Science 9, 37-48 (2005)

${ }^{58}$ Z. Gu and P. B. Balbuena, J. Phys. Chem. C 111, 9877-9883 (2007).

${ }^{59}$ A. Kokalj, A. Lesar, M. Hodoscek, M. Causa, J. Phys. Chem. B 103,7222-7232 (1999).

${ }^{60}$ D. C. Ford, Y. Xu, M. Mavrikakis, Surface Science 587, 159-174 (2005).

${ }^{61}$ J. A. Herron, S. Tonelli, M. Mavrikakis, Surface Science 614, 64-74 (2013).

${ }^{62}$ G. Henkelman, A. Arnaldsson, H. Jónsson, Comput. Mater. Sci. 36, 354-360 (2006).

${ }^{63}$ E. Sanville, S. D. Kenny, R. Smith, G. Henkelman, J. Comp. Chem. 28, 899-908 (2007).

${ }^{64}$ L. Yang, M. B. Vukmirovic, D. Su, K. Sasaki, J. A. Herron, M. Mavrikakis, S. Liao, R. R. Adzic, J. Phys. Chem. C 117, 1748-1753 (2013).

${ }^{65}$ T. Bligaard, J. K. Nørskov, Electrochimica Acta 52, 5512-5516 (2007).

${ }^{66}$ R. R. Adzic, Electrocatalysis (Frontiers in Electrochemistry), p 197 edited by J. Lipkowski, P. N. Ross, Wiley-VCH: New York (1998).

${ }^{67}$ A. U. Nilekar, M. Mavrikakis, Surf. Sci., 602, L89-L84 (2008).

${ }^{68}$ C. F. Zinola, A. J. Arvia, G.L. Estiu, E. A. Castro, J. Phys. Chem., 98, 7566-7576 (1994).

${ }^{69}$ E. Leiva, C. Sánchez, Handbook of Fuel Cells - Fundamentals, Technology and Applications, Ch. 11, Vol. 2, edited by W. Vielstich, H. A. Gasteiger, A. Lamm, John Wiley \& Sons, Ltd (2010).

${ }^{70}$ N. Cabello - Moreno, E. M. Crabb, J. M. Fisher, A. E. Russell, D. Thompsett, ECS Transactions, 16 (2) 483-496 (2008)

${ }^{71}$ J.-Y. Park, M. A. Scibioh, S.-K. Kim, H.-J. Kim, I.-H. Oh, T. G. Lee, H. Y. Ha, Int. J. Hydrogen Energy, 34, 2043 - 2051 (2009)

72 J.-Y. Park, J.-H. Kim, Y. Seo, D.-J.Yu, H. Cho, S. J. Bae, Fuel Cells 12, (3), 426-438 (2012)

${ }^{73}$ J.-Y. Park, J.-H. Lee, J. Sauk, I.-H. Son, Int. J. Hydrogen Energy, 33, 4833-4843 (2008) 